\title{
El Alto Valle del Guadiato durante la Prehistoria reciente: El poblamiento Neolítico y Calcolítico
}

\section{The Alto Valle del Guadiato during the Recent Prehistory: The settlement Neolithic and Cooper Age}

\author{
Beatriz Gavilán Ceballos*
}

\section{RESUMEN}

Ofrecemos en este trabajo una visión general del poblamiento neolítico y calcolítico en el Alto Valle del Guadiato. Aunque hemos publicado otros trabajos sobre la zona, la documentación derivada de la excavación que efectuamos en el Dolmen de las Casas de Don Pedro de 2001 ha conllevado un cambio en el conocimiento que teníamos sobre la

Prehistoria Reciente del sector, habiéndose documentado con toda claridad una ocupación que arranca desde

finales del $V$ milenio.

\section{PALABRAS CLAVE}

Hábitats, sepulcros megalíticos, Neolítico,

Calcolítico.

\section{ABSTRACT}

In this study we offer a general opinion about the Neolitihic/Copper age settlement in the Alto Valle del Guadiato. We have already published other studies of the area, viz. Excavation of the Dolmen de las Casas de Don Pedro in 2001. In part the results of the excavation of the Dolmen have supported a change of opinion about the recent Prehistory of the zone which without doubt had its beginnings at the end of the $\mathrm{V}$ millenium b.c.

\section{KEY WORDS}

Sites, megalitihic sepulchres, Neolithic, Cooper Age.

1 Profesora Titular del Área de Prehistoria, Departamento de Historia 1, Facultad de Humanidades, Universidad de Huelva, Campus del Carmen. Avenida de las Fuerzas Armadas, s/n. 21071 Huelva. beatriz.gavilan@dhis1.uhu.es 


\section{INTRODUCCIÓN}

El río Guadiato nace en La Calaveruela (Fuente-Obejuna), al noroeste de la provincia de Córdoba y próximo al límite con la de Badajoz, discurriendo en dirección este-sureste hasta La Angostura, en Espiel, desde donde continúa hacia el suroeste para desembocar en el Guadalquivir a la altura de Almodóvar del Río. En su primer tramo, que se desliza por terrenos de edad precámbrica y paleozoica, existe una serie de cerros testigos que configuran un paisaje característico, dando nombre el río a una comarca natural denominada Alto Valle del Guadiato, que alcanza desde Fuente Obejuna hasta Villaviciosa de Córdoba. En este trabajo sólo atendemos al tramo inicial del río, que va desde su nacimiento hasta justo el primer encajonamiento, a la altura de la Sierra del Castillo, en Espiel (Mapa 1), puesto que aunque tras éste vuelve a formar un amplio valle, está actualmente bajo las aguas del Pantano de Puente Nuevo.

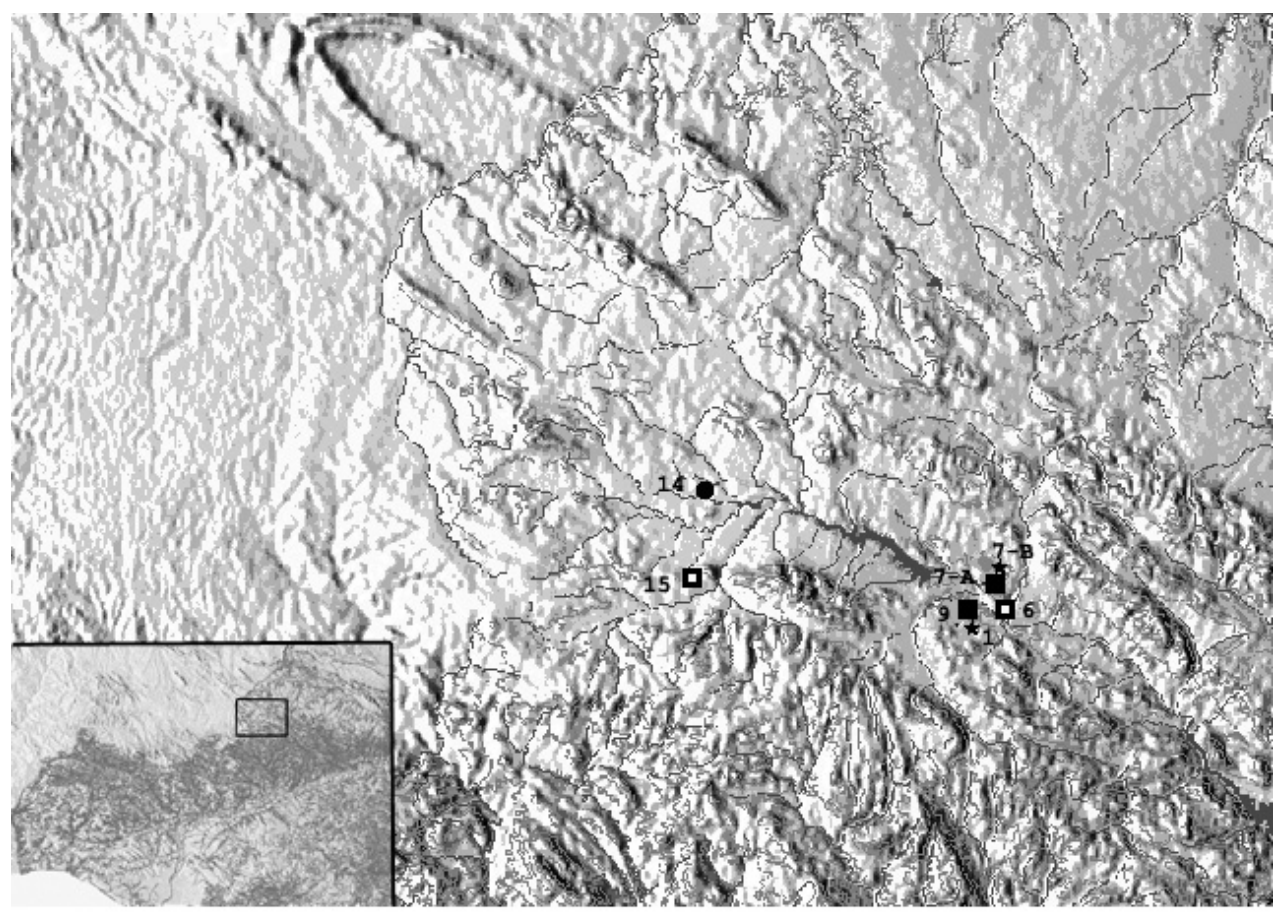

Neolitico Antiguo/Medio: 9: Casas de Don Pedro; 7-A: Cueva Agustín.

口 Neolitico Tardio/Final: 6: Sierra Palacios II; 15: Cerro del Castaño.

- Tránsito Neolitico Calcolitico: 14: Las Calerillas.

* Enterramientos neoliticos: 7-B: Cueva de Agustín; 1: $1^{\text {a }}$ fase del Dolmen de las Casas de Don Pedro.

Mapa 1. Alto Valle del Guadiato. Yacimientos neolíticos y de transición Neolítico/Calcolítico. 


\section{A MODO DE SÍNTESIS SOBRE LA INVESTIGACIÓN}

Hasta la década de los 80 del pasado siglo las noticias sobre la Prehistoria reciente del Alto Valle del Guadiato tratan exclusivamente sobre los numerosos megalitos existentes en la zona, debiéndose a A. Carbonell la localización de muchos de ellos (Carbonell, 1923, 1925, 1945, 1949), en cuyas notas se fundamentaron los Leisner (1943) al realizar su corpus que, a su vez, sirvió de apoyo a R. Cabrero (1988 a) en su Tesis Doctoral, en la que incluye megalitos cordobeses, publicando también una monografía sobre el ajuar funerario de los sepulcros de Los Delgados I y II, excavados por A. Guzmán y situados en la finca de su propiedad (Cabrero, 1988 b). Sin pretender restar mérito a estos trabajos, el interés se centraba principalmente en las arquitecturas megalíticas y, en ocasiones, en sus ajuares funerarios, pero no se establecía relación alguna entre sepulcros y lugares de hábitat, de los que, ciertamente se conocían pocos, excepción hecha de la que establece R. Cabrero entre el yacimiento de Los Delgados y los dos sepulcros del mismo nombre.

Las referencias claras acerca de poblados las proporcionan J. Bernier, sobre Sierra Palacios (Bernier et alii, 1981), y Blázquez (1981), quien realizó un sondeo en Los Castillejos de Fuente Obejuna con motivo de su excavación en la Mima de la Loba.

A partir de mediados de la citada década se empieza a prestar verdadera atención a los lugares de hábitat, realizándose Memorias de Licenciatura y trabajos de síntesis sobre determinados yacimientos - La Calaveruela y los Castillejos, en Fuente Obejuna- (Murillo, 1986 a y b). Las primeras excavaciones científicas corren a cargo de la firmante, en 1985, en el poblado de Sierra Palacios (Belmez), y en el Dolmen de las Casas de Don Pedro al año siguiente (Gavilán, 1986 a y b, 1987 a y b), realizándose una segunda campaña en este megalito en 2001, ahora en codirección con J.C. Vera (Gavilán y Vera, 2001). Las dos primeras intervenciones de urgencia motivaron un Proyecto de Prospección Arqueológica de Urgencia, concedido por la Delegación Provincial de Cultura de Córdoba y dirigido por quien suscribe, ante el expolio a que estaban siendo sometidos gran parte de sepulcros megalíticos del Alto Valle del Guadiato. Entre los resultados de este Proyecto destacamos la revisión de numerosas sepulturas conocidas de antiguo y la localización tanto de nuevos dólmenes cómo de asentamientos, que fuimos dando a conocer en los Anuarios Arqueológicos de Andalucía (Gavilán et alii, 1991), congresos (Gavilán y Vera, 1994) y revistas (Gavilán y Vera, 1989-90), o bien constituyeron la base de Memorias de Licenciatura (Cepillo, 1994; Vera, 1995) y una Tesis Doctoral (Vera, 1999), dirigidas por la firmante.

Algunos de estos trabajos ya han sido publicados, habiendo ofrecido una aproximación al conocimiento del poblamiento del Alto Valle del Guadiato (Gavilán y Vera, 1989-90), pero creemos necesario volver sobre el tema debido, por un lado, a que contamos con nuevos datos de interés que aconsejan esta revisión, y 
por otro, a un cambio de postura acerca de la adscripción cronocultural de determinados conjuntos materiales, como es el caso de los asentamientos que han proporcionado cazuelas carenadas y en los que están ausentes los platos de borde engrosado, o bien aquellos que han ofrecido ambas formas cerámicas.

\section{PROPUESTA DE PERIODIZACIÓN}

Ante la ausencia de dataciones absolutas y de amplias secuencias estratigráficas en la zona, la periodización que establecemos se basa, lógicamente, en la ergología, que nos permite defender la existencia de yacimientos perfectamente encuadrables en el Neolítico y el Calcolítico.

Neolítico: Adjudicamos a este período los yacimientos que han proporcionado conjuntos industriales fechables a mediados del $\mathrm{V}$ y el IV milenios a.C., entre los que sobresalen las cerámicas de formas globulares y con decoraciones a la almagra, incisas, impresas, etc., y los que han proporcionado cazuelas carenadas, estando ausentes los platos de borde engrosado, que pueden situarse desde finales del IV milenio hasta el primer tercio del III a.C.

En relación a estos últimos asentamientos, que atribuimos en anteriores trabajos al Calcolítico Antiguo (Gavilán y Vera, 1989-90), los incluimos ahora en los momentos finales del Neolítico ante el avance de la investigación, estando de acuerdo con los argumentos aducidos por J.L. Escacena (Escacena et alii, 1996) y otros investigadores (Pérez et alii, 1999; Cámara et alii, 2005).

Transición Neolítico-Calcolítico y/o Calcolítico Inicial: Presente en los hábitats que aún proporcionan cazuelas carenadas pero ya con platos de borde engrosado, incluyendo en el Calcolítico Inicial a aquellos que han aportado un volumen más elevado de las segundas formas con respecto a las primeras.

Queremos remarcar que al tratarse de restos carentes de contexto no puede descartarse una primera ocupación de algunos de estos asentamientos a partir del Neolítico Final, continuando durante el Calcolítico Inicial, de manera que la transicionalidad que aparentan estos restos quizá se deba no necesaria y exclusivamente a una ocupación monofásica, sino a la mezcla de materiales que en superficie ofrecen los yacimientos con distintas fases ocupacionales.

Calcolítico Pleno y Final: En la primera fase incluimos los yacimientos con abundantes platos de borde engrosado y almendrado, mientras que las cazuelas carenadas están ya ausentes o sólo tienen un valor puramente testimonial. Por su parte, la cerámica campaniforme, presente en algunos, indica una continuidad habitacional hasta los momentos finales del Calcolítico, alcanzando el cambio de milenio.

Se nos puede objetar que se trata de una periodización un tanto simplista y encorsetada, pero queremos indicar en nuestro favor que sólo se han excavado 
dos asentamientos: El localizado en el lugar sobre el que se levantará el Dolmen de las Casas de Don Pedro, monofásico y correspondiente a finales del $\mathrm{V}$ y/o comienzos del IV milenios, y Sierra Palacios I, de mediados del III milenio y en cuya estratigrafía no se advierten cambios importantes que permitan mayores precisiones. Ciertamente, somos conscientes de que a lo largo del Neolítico Final y todo el Calcolítico se produjeron grandes transformaciones que afectaron no sólo al ámbito artefactual cerámico sino a todos los niveles, que aconsejan si no una mayor subdivisión, sí importantes matizaciones, como se manifiesta en diversos asentamientos ampliamente excavados - v.gr. Castillejos de Montefrío- (Cámara et alii, 2005), pero proponerlas en este trabajo con la documentación disponible sería pura conjetura.

\section{LOS ASENTAMIENTOS}

A continuación ofrecemos las características generales que han proporcionado los asentamientos, citándolos de Este a Oeste.

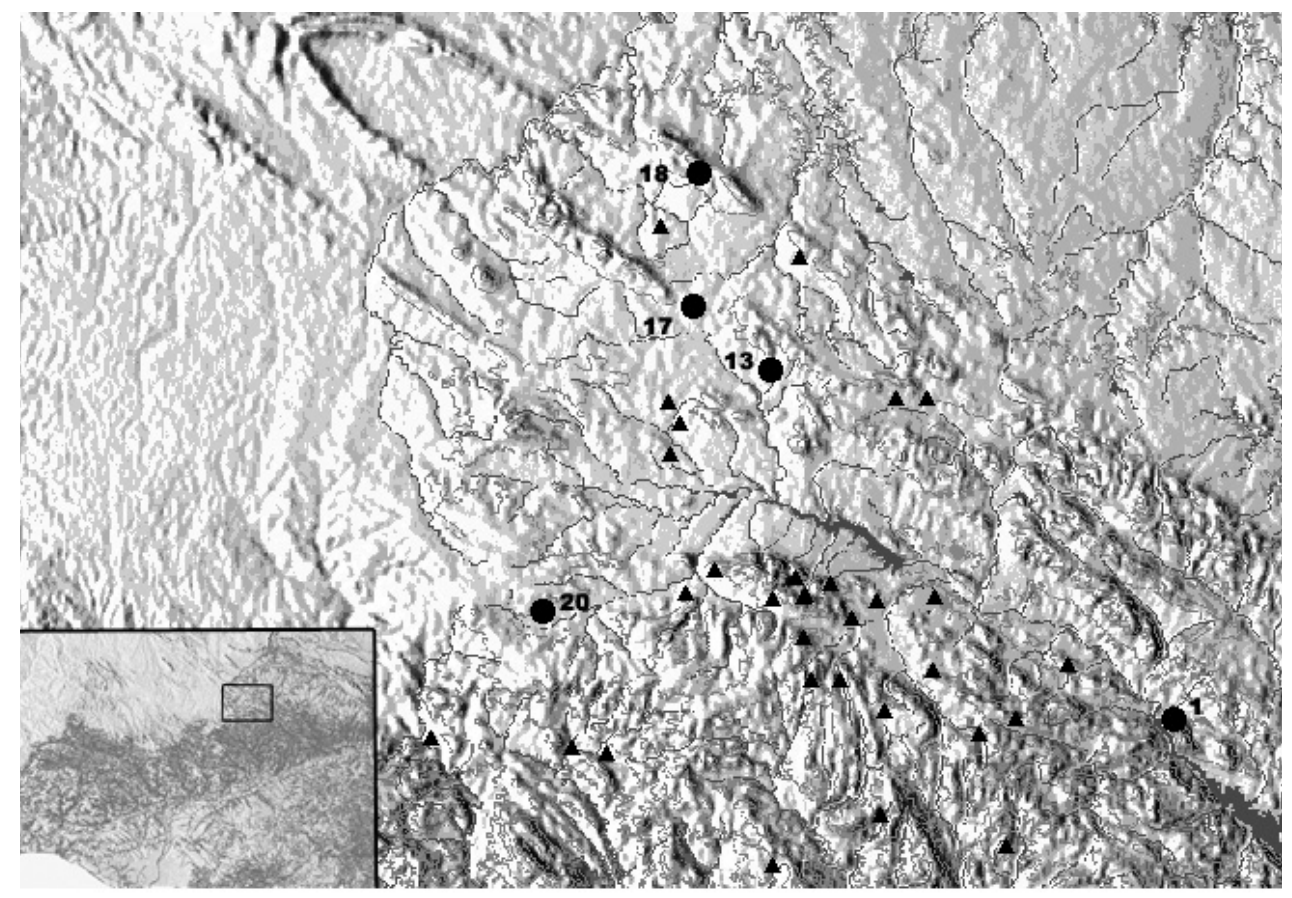

Yacimientos: 1: Huerta del Caño; 13: El Calvario o La Granjuela I; 17: Los Castillejos de La Granjuela; 18: La Cinta; 20: Los Delgados.

A Afloramientos de cobre.

Mapa 2. Alto Valle del Guadiato: Calcolítico Inicial. 


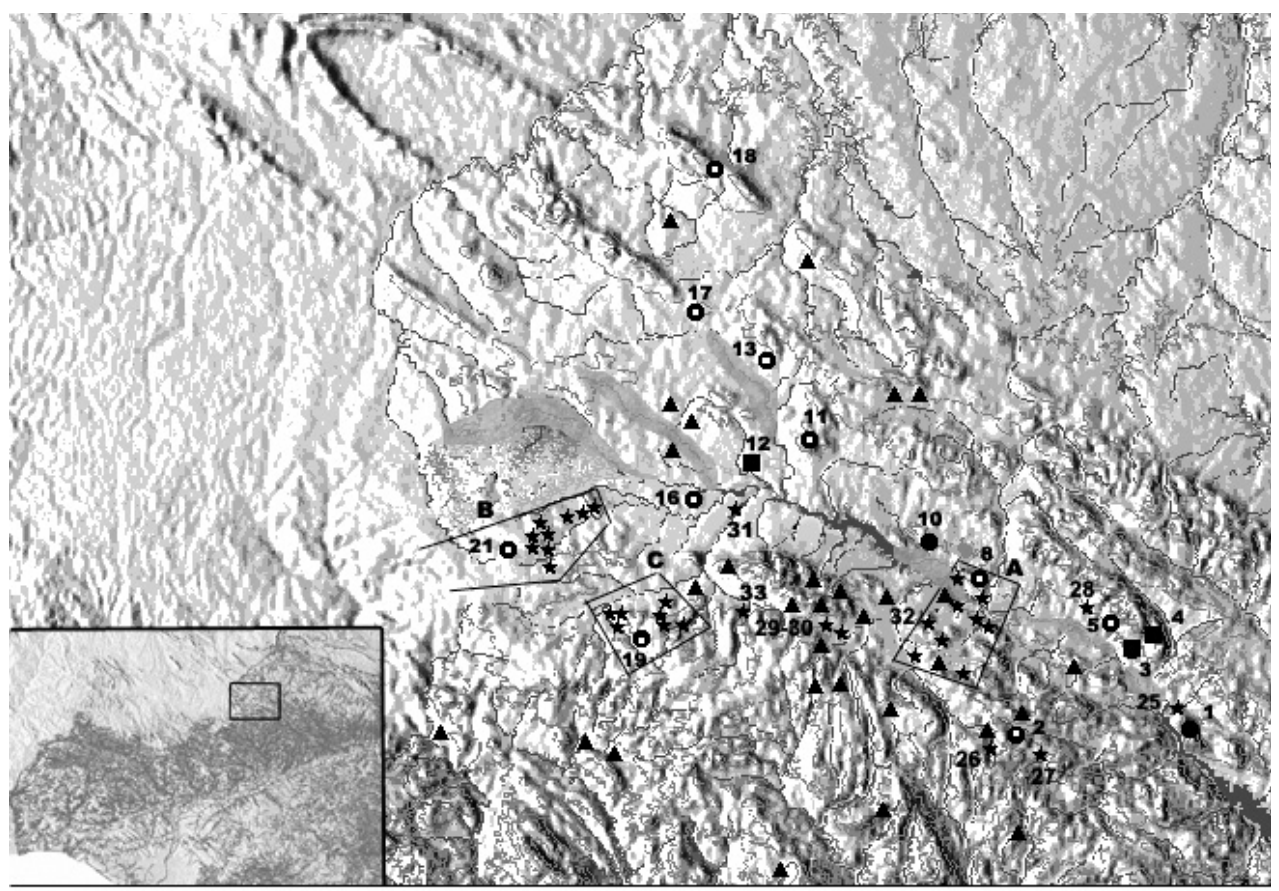

Calcolitico Pleno: 1: Huerta del Caño; 2: Cerro del Ermitaño; 5: La Cornuda; 8: Sierra Palacios I; 10:

- Calcolítico Plenol Castillo de Belmez, 11: El Peñón; 16: Castillejos de Fuente-Obejuna; 17: CastilleFinal. jos de La Granjuela; 18: La Cinta; 19: Cerro de las Piedras; 21: La Calaveruela.

- Calcolitico S/D: 3: La Lozana; 4: Cerro del Molino; 12: Cerro de Masatrigo.

* Enterramientos:

Necrópolis: A: Sierra Palacios ( $n^{\circ} 1$ a 8$)$. B: La Calaveruela ( $n^{\circ} 16$ a 24). C: Cerro de las Piedras ( $n^{\circ} 9$ a 15$)$.

Túmulos y dólmenes: 25: Pantano de Puente Nuevo; 26: Puerto Cacho; 27: K-17; 28: La Jabalina o San Antonio; 29 y 30: Doña Rama I y II; 31: El Soto Bajo; 33: Los Pánchez. Otros enterramientos: 32: La Retuerta.

A Afloramientos de cobre.

Terrenos de vega.

Mapa 3. Alto Valle del Guadiato: Calcolítico Pleno y Final.

- Huerta del Caño: Se localiza en las coordenadas $38^{\circ} 11^{\prime} 07^{\prime \prime}$ norte y $5^{\circ} 02$ 15" oeste del M.T.N. E. 1:50.000 (Hoja 880), a unos $100 \mathrm{~m}$ sobre el Guadiato y en la estribación de la Sierra del Castillo de Espiel (Mapas 2 y 3, n. ${ }^{\circ 1}$ ).

Ha proporcionado varias hachas pulimentadas, un ídolo placa, martillos y fragmentos de cerámica que fueron dados a conocer por Carbonell (1922, 1947 b), así como un ídolo placa procedente de una de las covachas existentes en el Cerro del Castillo de Espiel, para el que Vera (1999) defiende un contexto funerario. Años más tarde, Murillo (1986 a) realiza una prospección, localizando más materiales. 
Las cazuelas carenadas son escasas, siendo abundantes los platos de borde engrosado y almendrado, vasijas de tres cuartos de esfera, formas con cuello, cuencos de variada tipología, queseras y un soporte; la cerámica decorada se reduce a algún fragmento de almagra. El resto de los materiales lo integran hachas y un martillo de minero, una cuenta de collar, un fragmento de lezna de cobre, escorias de fundición, cuarzos con el mismo mineral, un fragmento atribuible a una tobera, un cuernecillo y placas perforadas.

En función de los citados restos, para Murillo (1986 a) este hábitat se iniciaría a comienzos del Calcolítico, sin embargo, Vera (1999) lo adscribe al Calcolítico Pleno. En nuestra opinión, las características ergológicas - con presencia de cazuelas carenadas-, indican que la ocupación debió comenzar durante el Calcolítico Inicial continuando a lo largo de la plenitud del período.

Próximo a este hábitat se encuentra un túmulo situado en la margen derecha del Guadiato (Mapa 3, n. ${ }^{\circ}$ 25) sólo visible cuando descienden las aguas del Pantano de Puente Nuevo. La denominación que le damos es Túmulo 1 del Pantano de Puente Nuevo.

- Cerro del Ermitaño: Se localiza en las coordenadas $38^{\circ} 10^{\prime} 30^{\prime \prime}$ norte y $5^{\circ} 6^{\prime}$ 45" oeste del M.T.N. E. 1:50.000 (Hoja 880), a unos 720 m.s/n.m. y al sureste de la población de Villanueva del Rey, aunque en el T.M. de Espiel (Mapa 3, n. 2).

Ha proporcionado platos de borde engrosado, formas globulares, cuencos, así como plaquetas y cuernecillos; la industria lítica tallada la integran lascas laminares retocadas junto con alguna escotadura. Estos restos remiten a una ocupación correspondiente al Calcolítico (Murillo, 1986 a), pero Vera (1999) indica la presencia de otros materiales más avanzados que sitúa en el Bronce Final. Independientemente de estos últimos restos de cronología más avanzada, en lo que a la adjudicación calcolítica se refiere, nos mostramos de acuerdo con ambos autores.

Próximos a este hábitat se encuentran dos sepulcros megalíticos: Puerto Cacho y el Túmulo K-17 (Mapa 3, n. 26 y 27) (Gavilán et alii, 1989).

- La Lozana: Se localiza en las coordenadas $38^{\circ} 13^{\prime} 20^{\prime \prime}$ norte y $5^{\circ} 3^{\prime} 45^{\prime \prime}$ oeste del M.T.N. E.1:50.000 (Hoja 880), en un pequeño promontorio que se eleva a unos 540 m.s./n.m. sobre el Arroyo de La Lozana (Mapa 3, n. ${ }^{\circ}$ 3).

El material se reduce a restos de talla, núcleos y material retocado y sin retocar, junto a hachas y un fragmento de molino. Para este hábitat, que dista unos $2.800 \mathrm{~m}$ del de La Cornuda, Vera propone una ocupación estacional en función de la explotación de recursos líticos y dependiente de aquella, de mayor entidad (1999).

- Cerro del Molino: Sus coordenadas son $38^{\circ} 13^{\prime} 00^{\prime \prime}$ norte y $5^{\circ} 02^{\prime} 44^{\prime \prime}$ oeste del M.T.N. E.1:50.000 (Hoja 880), se localiza sobre una pequeña elevación de unos 520 m.s/n.m. (Mapa 3, n. ${ }^{\circ} 4$ ). Se encuentra a unos $1.800 \mathrm{~m}$ del anterior, tratándose de un tipo de asentamiento de similares características en lo que a tipo de 


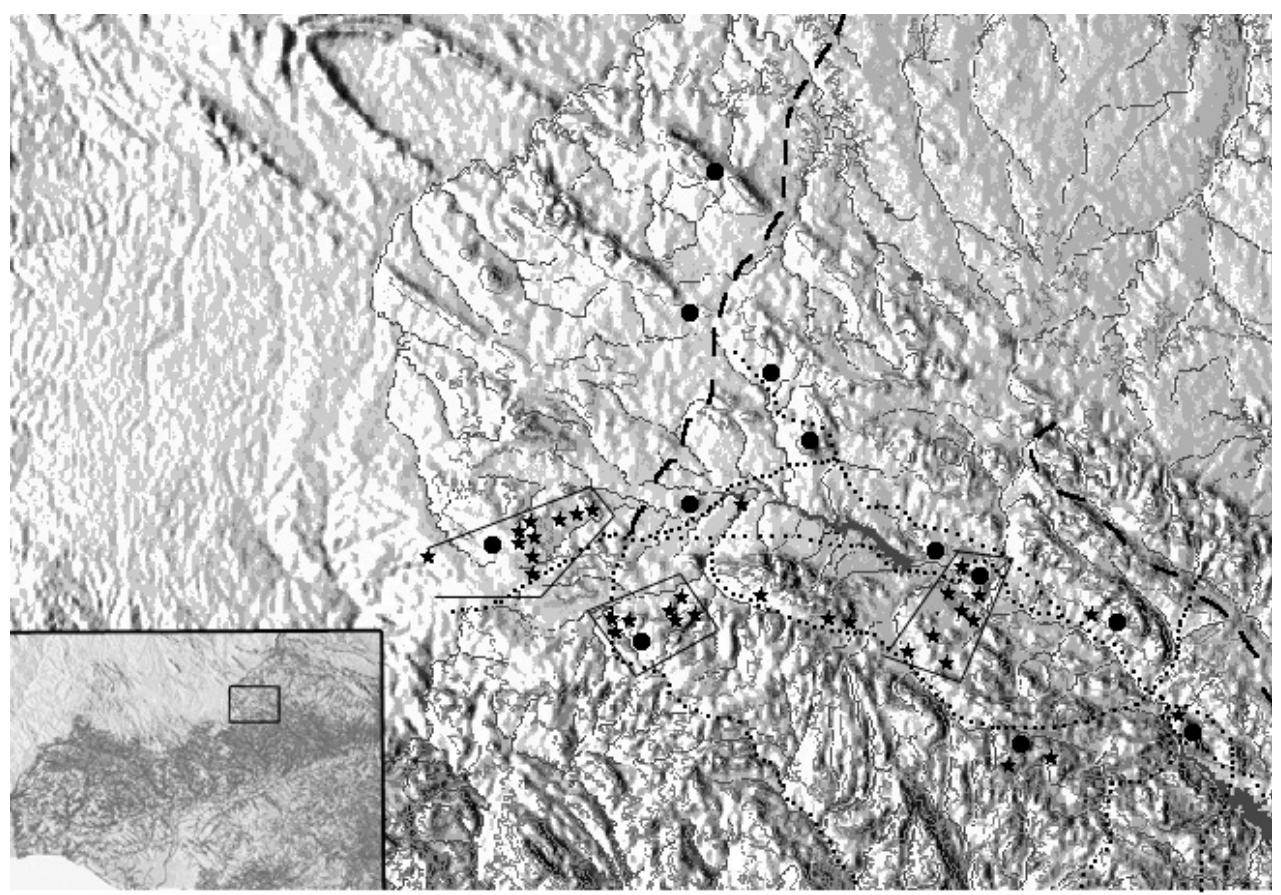

- Cañada Real: A: Segoviana, B: Riojana.

... Cordeles, veredas y coladas.

Mapa 4. Alto Valle del Guadiato. Situación de los principales poblados calcolíticos y las sepulturas megalíticas en relación a los pasos naturales de comunicación/vías pecuarias.

ocupación se refiere, habiendo proporcionado fragmentos de platos de borde engrosado, cuencos y un hacha; si bien escasos, pueden situarse en el Calcolítico (Murillo, 1986 a).

- La Cornuda: Se localiza en las coordenadas $38^{\circ} 12^{\prime} 55^{\prime \prime}$ norte y $5^{\circ} 05^{\prime} 30^{\prime \prime}$ oeste del M.T.N. E. 1:50.000 (Hoja 880). En un cerro aislado, si sitúa prácticamente en el centro del Alto Valle del Guadiato, a unos 540 m.s./n.m. (Mapa 4, n. ${ }^{\circ} 13$ ).

Entre los materiales destacan los fragmentos de platos de borde engrosado, cuencos y vasijas globulares, así como un fragmento de campaniforme; puntas de flecha y hojas con y sin retoque. La adjudicación propuesta es la de Calcolítico Pleno y Final (Vera, 1999), estando de acuerdo con dicha adscripción.

En las inmediaciones de este asentamiento se encuentra el Dolmen de La Jabalina o San Antonio, con presencia de campaniforme en el túmulo (Mapa 3, n. $\left.{ }^{\circ} 28\right)$.

- Sierra Palacios II: Se localiza en las coordenadas $38^{\circ} 15^{\prime} 11^{\prime \prime}$ norte y $5^{\circ} 11^{\prime}$ 3" oeste del M.T.N. E. 1:50.000 (Hoja 880). Está emplazado en la ladera sur del 
conjunto montañoso de Sierra Palacios, a unos 500 m.s./n.m. y a 30 m. sobre el Guadiato, que fluye a unos $1.200 \mathrm{~m}$. de distancia (Mapa 1, n. ${ }^{\circ}$ ).

La industria lítica tallada consta de hojas y lascas retocadas, puntas de flecha de base recta, hojas de dorso, truncaduras, un taladro, un raspador, una escotadura, un trapecio, una escotadura-truncadura y un microburil (Fig. 1); el material no retocado se distribuye entre hojas y lascas. La cerámica no decorada es abundante, destacando las cazuelas carenadas y formas derivadas de la esfera (Figs. 2 y 3); las decoraciones incisas, acanaladas, almagras y a base de cordones están presentes. En piedra pulimentada se cuenta con dos fragmentos de hacha y otros tantos de plaquetas. Una cuenta de collar obtenida a partir de una porción de «tallo de crinoides» (fósil usual en la formación caliza de Sierra Palacios) y una lezna completan la ergología del asentamiento (Fig. 1).

Con anterioridad (Gavilán y Vera, 1989-90) adjudicamos este asentamiento a los inicios del Calcolítico, sin embargo, actualmente y teniendo en cuenta la amplia representación de cerámicas decoradas características del Neolítico, la abundancia de cazuelas carenadas y la total ausencia de platos de borde engrosado, opinamos que su ocupación pudo tener lugar a partir de mediados del Neolítico, afianzándose este hábitat a lo largo de la fase final de dicho período. Si bien no es atribuible a ninguna de las fases del Neolítico la lezna, cuya presencia no se explica satisfactoriamente por la cercanía de Sierra Palacios I, situado por encima y hacia el oeste de la formación, ni tampoco por las explosiones para la extracción de caliza, que han afectado a gran parte del hábitat de Sierra Palacios I, puesto que tanto en un caso como en otro cabría esperar una representación mayor y más variada de restos de cronología más reciente en Sierra Palacios II. Quizá deba entenderse, como apuntamos en otro trabajo (IBIDEM), como consecuencia de una intrusión posterior y fortuita.

Al hábitat de Sierra Palacios II corresponde la primera fase de construcción del Dolmen de las Casas de Don Pedro (Mapa 1, n. ${ }^{\circ}$ ), una cámara simple formada por los primigenios menhires y la adición de más ortostatos (Gavilán y Vera, 2005). Por su parte, atendiendo a la similitud del ajuar depositado en Cueva de Agustín con respecto al del anterior sepulcro, defendemos una cronología de $\mathrm{Ne}$ olítico Final para este enterramiento, para el que Vera propone una adscripción calcolítica (1999).

- Cueva de Agustín: Ubicada en Sierra Palacios, fue arrasada por una antigua cantera (Mapa 1, n. ${ }^{\circ}$-A). Aparte de los elementos correspondientes a un ajuar funerario, proporcionó algunos materiales cerámicos entre los que sobresalen un fragmento a la almagra con un asa de cinta horizontal y otro correspondiente a impresa de punto y raya asociada a un cordón liso, que remiten claramente a un Neolítico de la primera mitad del IV.

- Sierra Palacios I: Se ubica en una zona amesetada del conjunto serrano de Sierra Palacios. Sus coordenadas son $38^{\circ} 15^{\prime} 16^{\prime \prime}$ norte y $5^{\circ} 11^{\prime} 10^{\prime \prime}$ oeste del 

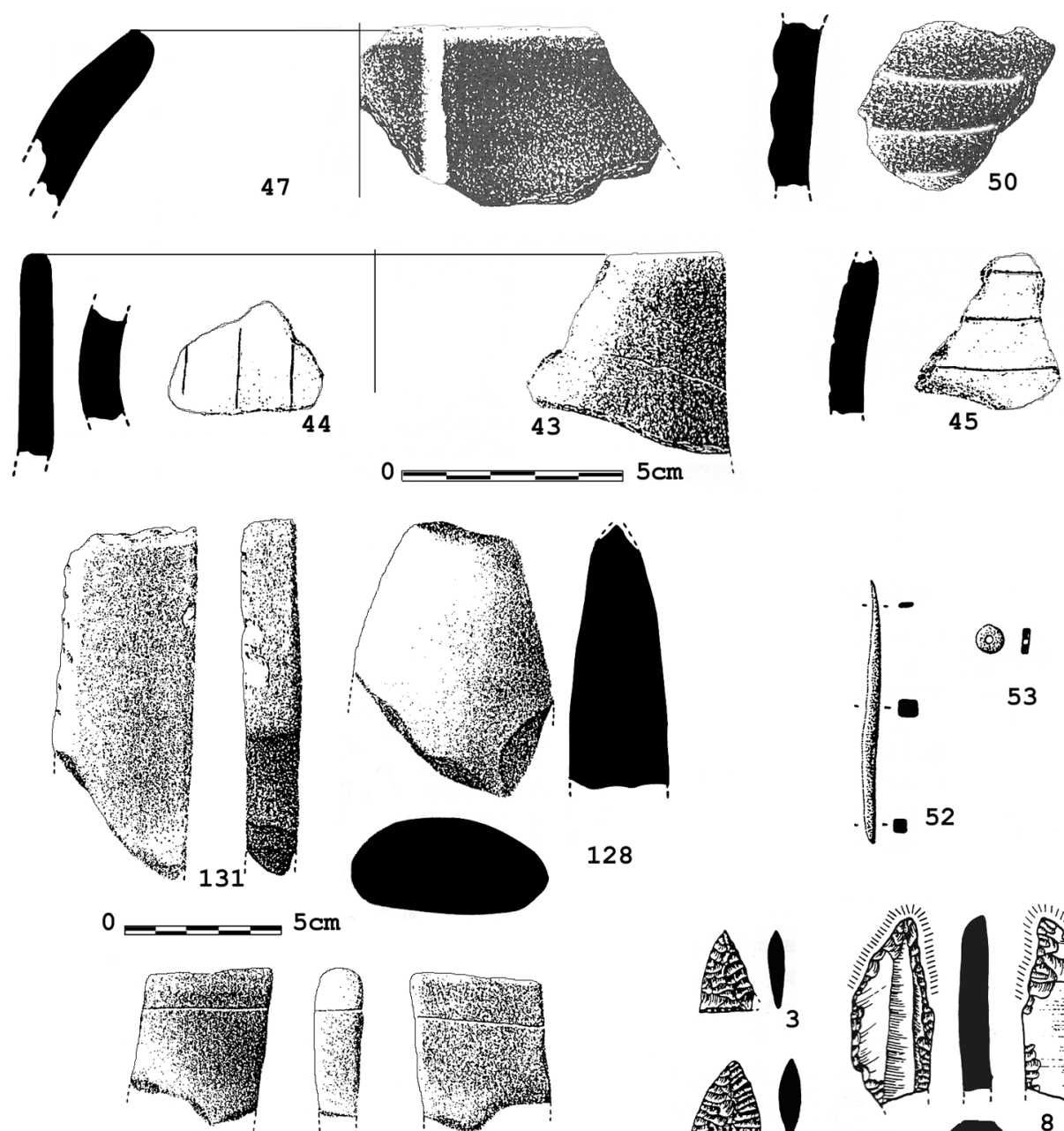

$5 \mathrm{~cm}$
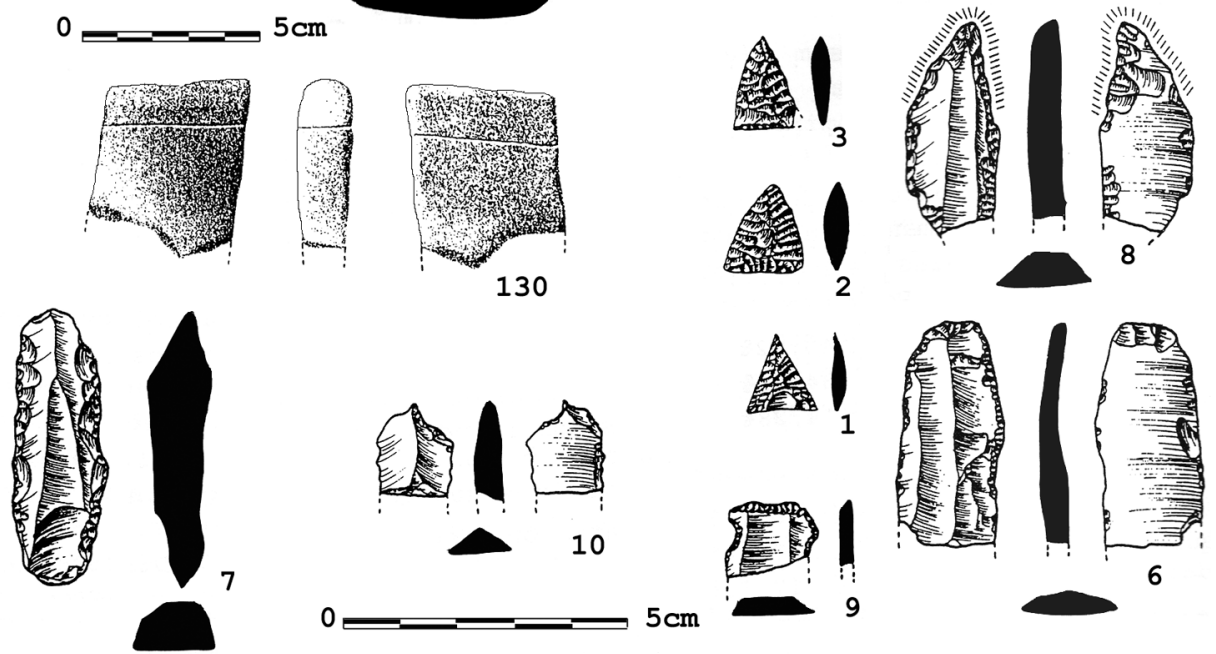

Fig. 1. Sierra Palacios II. Industria lítica y cerámicas decoradas. 

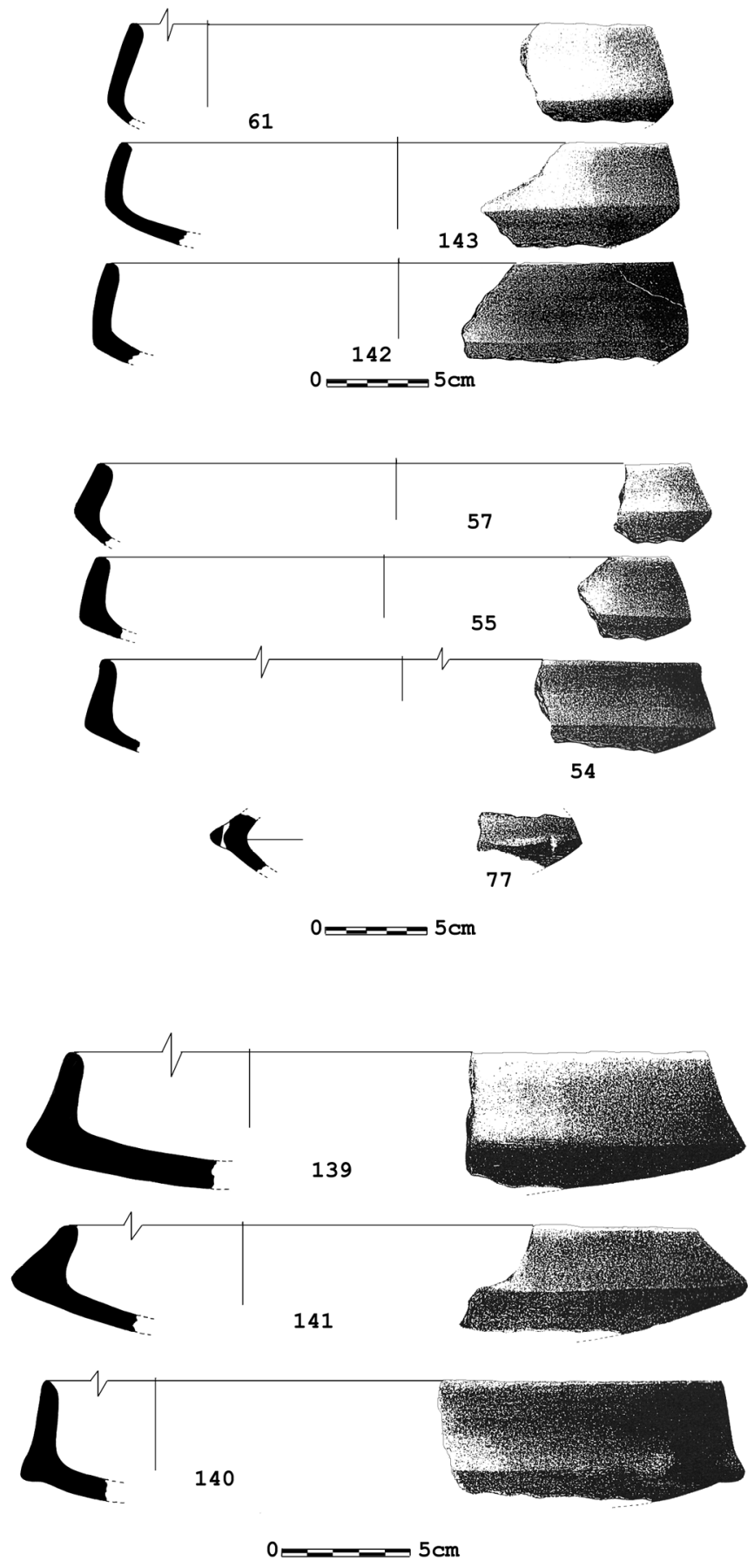

Fig. 2. Sierra Palacios II. Cazuelas carenadas. 


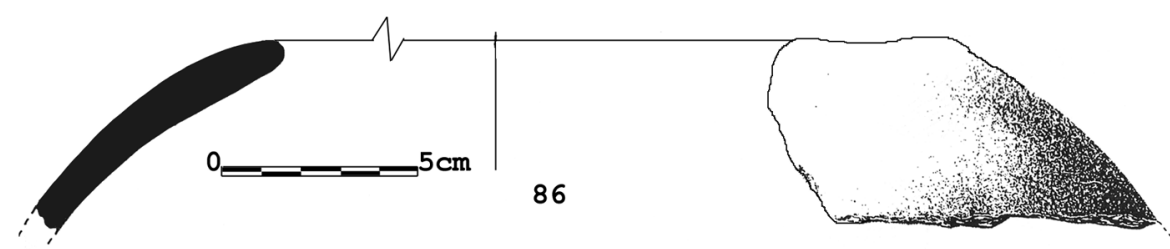

94
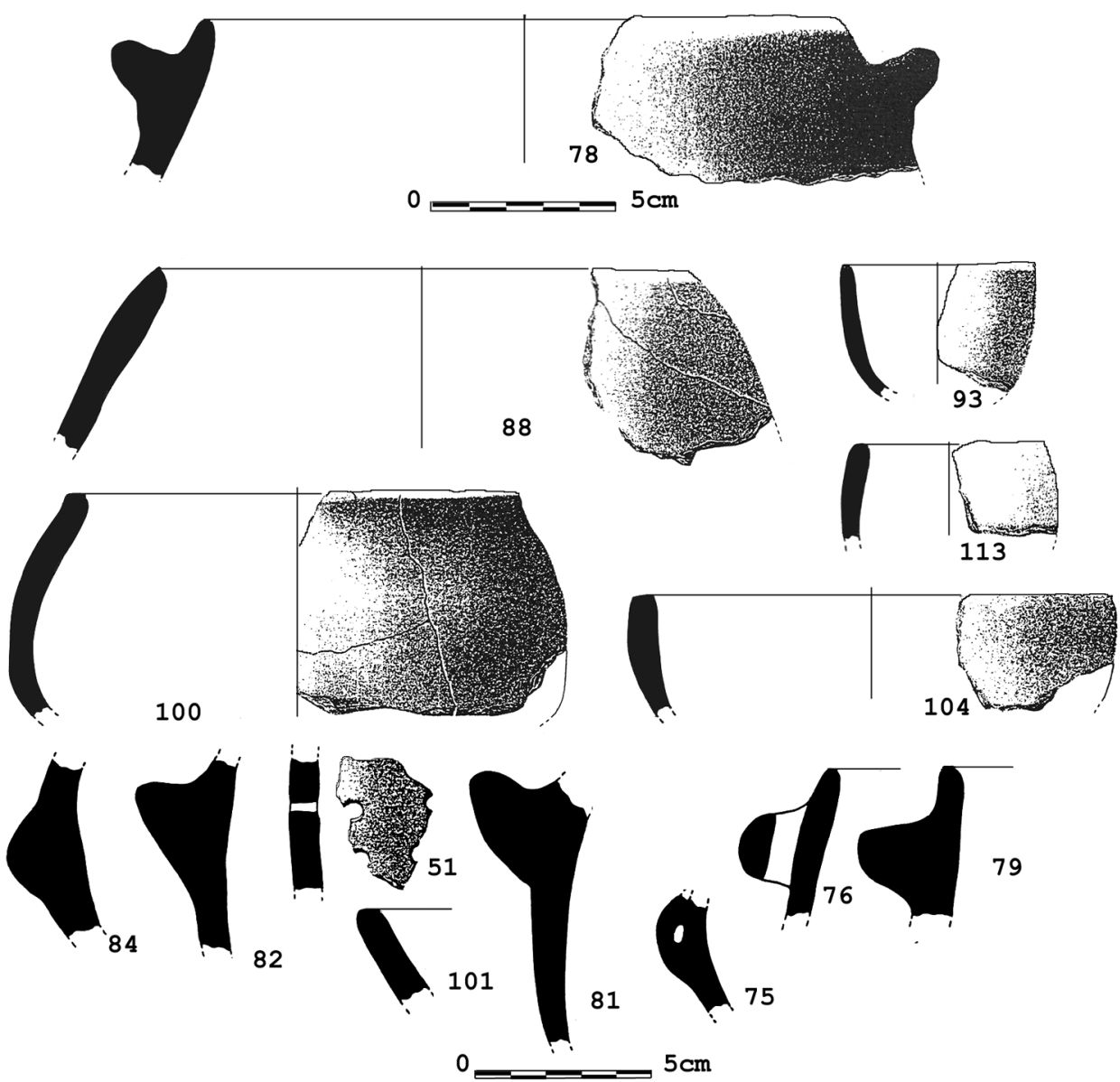

Fig. 3. Sierra Palacios II. Formas cerradas. 


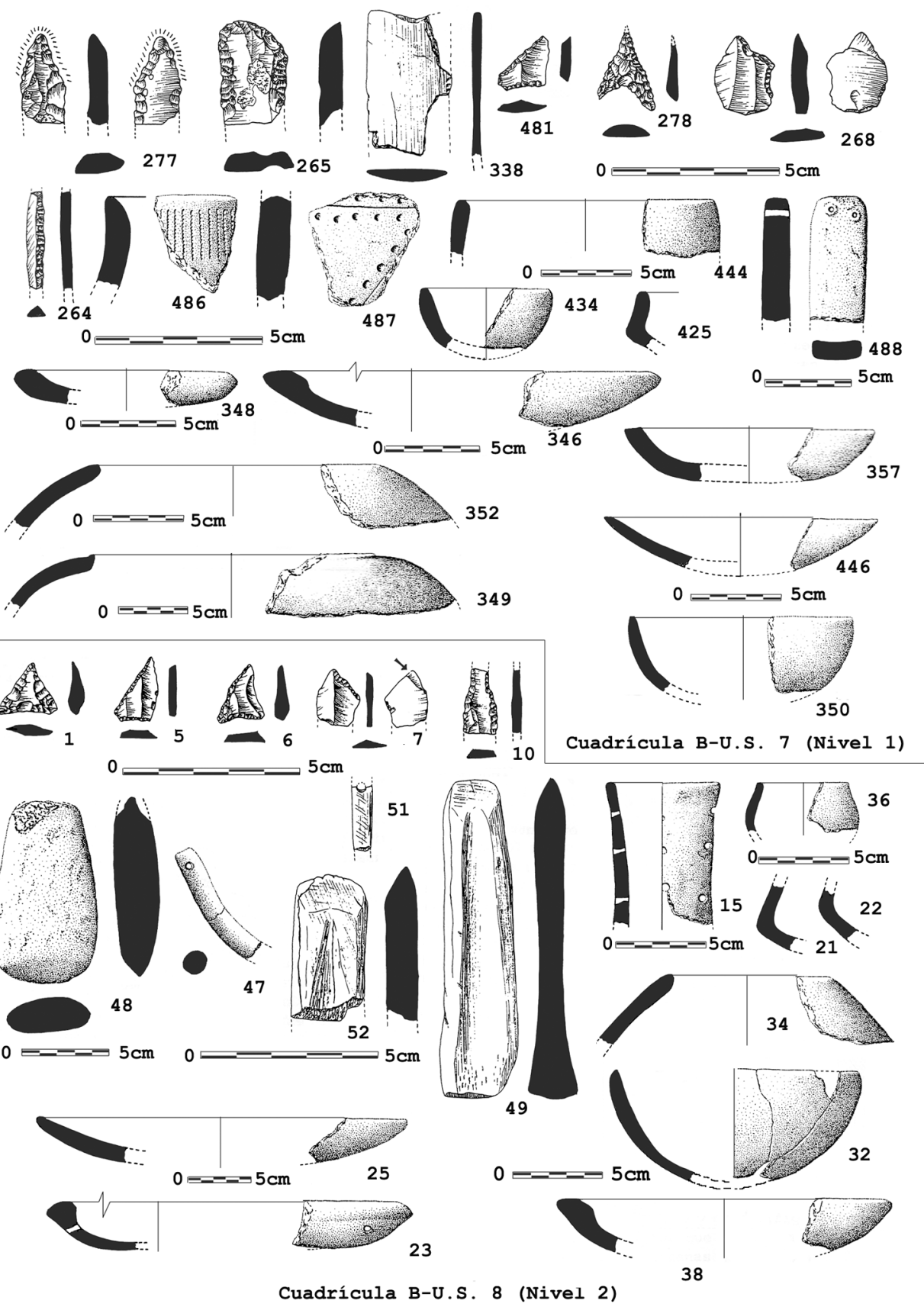

Fig. 4. Sierra Palacios I. Materiales procedentes de distintas UU.SS. de la cuadrícula B. 
M.T.N. E. 1: 50.000 (Hoja 880). Se eleva a unos $80 \mathrm{~m}$ sobre el Guadiato y unos 570 m.s/n.m. (Mapa 3, n. ${ }^{\circ} 8$ ).

Se trata de uno de los asentamientos más interesantes de todo el sector, habiéndose realizado una excavación de urgencia en 1985 ante la pérdida de parte del yacimiento ocasionada por la explotación de la caliza. Este asentamiento ha sido objeto de varios trabajos (Gavilán, 1986 a y b, 1987 a y b; Asquerino, 1985; Gavilán y Vera, 1989-90), constituyendo parte de la base documental de una Tesis Doctoral (Vera, 1999).

Practicamos dos cuadrículas que han proporcionado una sucesión estratigráfica relativamente corta pero interesante, con presencia de estructuras de planta circular construidas a partir de zócalos de piedra que apoyaban en bloques o directamente sobre la roca madre, asociándose a ellas derrumbes de adobes con improntas de cañizo.

Las cazuelas carenadas son escasas, mientras que los platos de borde engrosado y almendrado son muy abundantes, destacando también las vasijas globulares de tres cuartos de esfera, cuencos de media y tercio de esfera, cazos, queseras y soportes (Fig. 4). Algunos fragmentos presentan una decoración a la almagra, muy diluida, así como incisiones e impresiones. Por último, se documentaron los típicos «cuernecillos», plaquetas perforadas y adobes con improntas de cañizo. La industria lítica tallada destaca por la presencia masiva de puntas de flecha, algunos geométricos, taladros, dorsos, escotaduras, truncaduras, grandes hojas con o sin retoque, y escasos raspadores y dientes de hoz, mientras que son abundantes los restos de talla y de núcleos, testimonios de la elaboración de los artefactos de uso cotidiano. La industria ósea es muy numerosa, contándose con punzones, varillas, espátulas y tubos (Fig. 5 y 6). Por su parte, la piedra trabajada consta de piezas activas y pasivas de molinos, hachas y azuelas, como elementos más característicos.

Asimismo, artefactos de metal se documentaron en los niveles superiores de la cuadrícula A, tratándose de una laminita de oro enrollada, del nivel de Superficie, y fragmentos de mineral de cobre y un fragmento correspondiente a un crisol que contenía adherencia de cobre, en el nivel 1. Por su parte, en la cuadrícula B también se documentaron evidencias de metalurgia en los primeros niveles: En el de Superficie un fragmento de escoria, una chapa de cobre y un fragmento de crisol, y en el Nivel 1 un fragmento de mineral de cobre. Sobresalen los elementos cultuales mediante la presencia de ídolos tolva, cilindro, violín, planos y falange (Fig. 6)

Junto a los restos citados, destaca gran cantidad de fauna salvaje - suidos y cérvidos- y doméstica —ovicápridos y bóvidos, principalmente-, habiéndose documentado además el aprovechamiento de bivalvos fluviales.

Las características del material nos llevaron (Gavilán y Vera, 1989-90) a incluir este hábitat dentro del Calcolítico Pleno, con una ocupación esporádica en la 

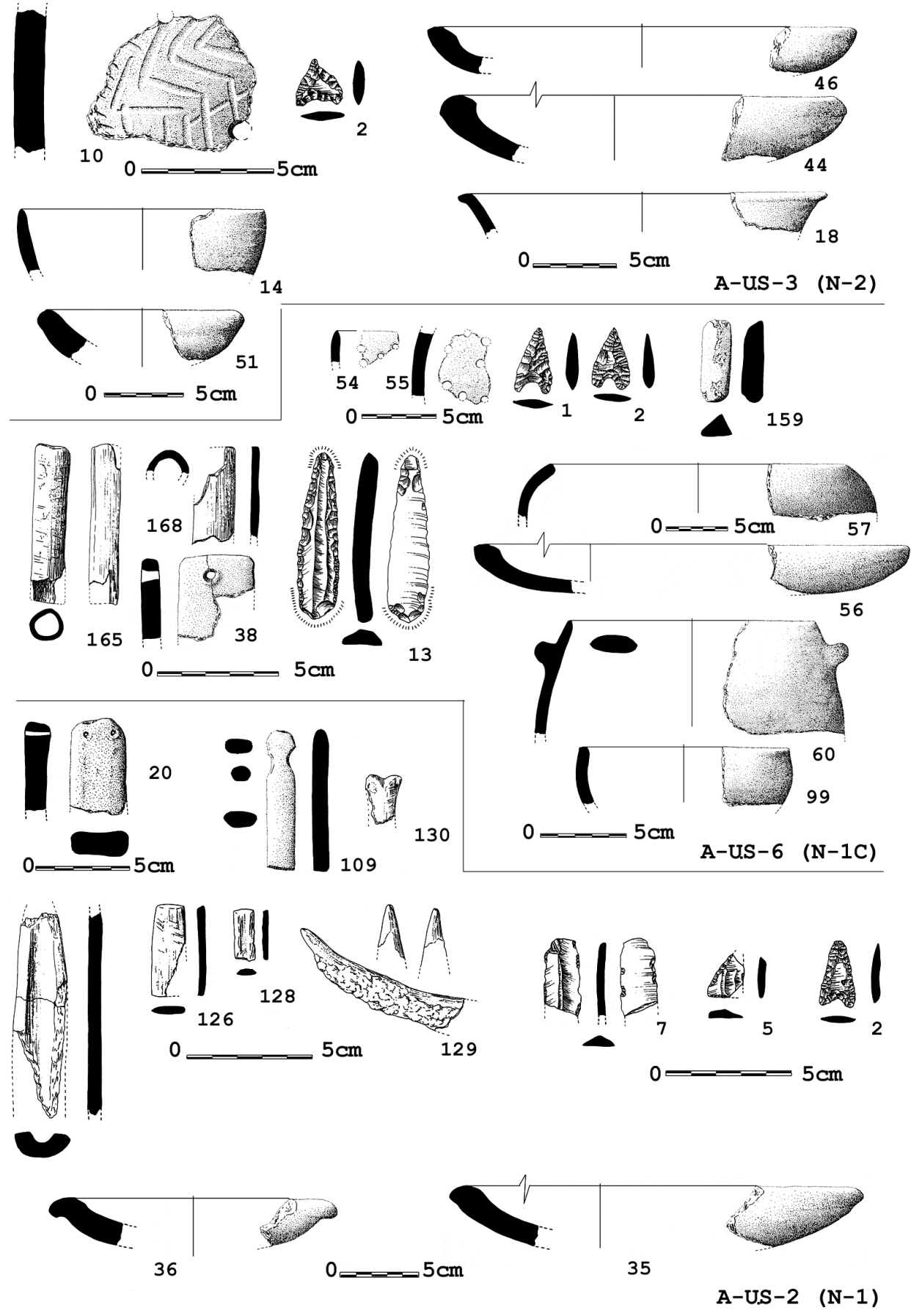

Fig. 5. Sierra Palacios I. Materiales procedentes de distintas UU.SS. de la cuadrícula A. 

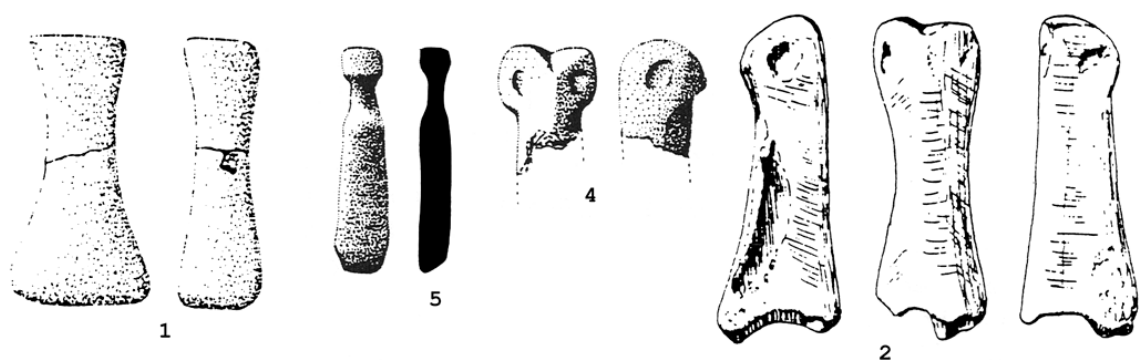

Cuadrícula A-U.S. 1 (N.S)
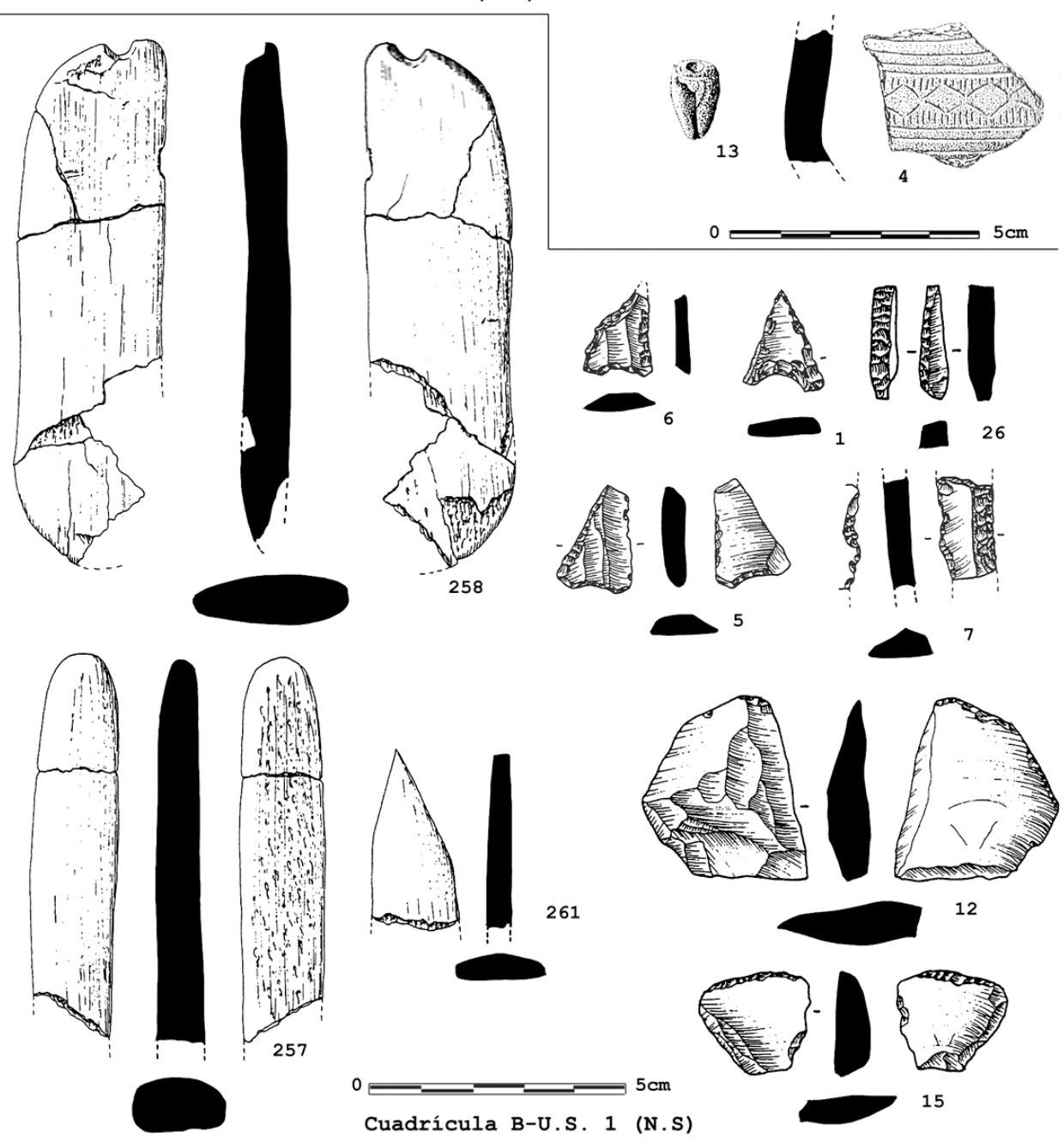

Fig. 6. Sierra Palacios I. Materiales procedentes de las cuadrículas A y B. 
fase Final a partir de la presencia de cerámicas campaniformes. Si tenemos en cuenta la existencia de algunas cazuelas carenadas, quizá no resulte descabellado plantear una ocupación de este sitio que arranca en los momentos finales de Calcolítico Inicial, aunque la mayor parte de los restos recuperados a lo largo de la excavación responden a la plenitud del período.

A este asentamiento atribuimos la necrópolis dolménica situada en su entorno e inmediaciones - algunos sólo distan unos centenares de metros-, localizándose los sepulcros al SO del poblado: Sierra Palacios I o Cabeza de Vaca, Sierra Palacios II o Sánchez Pastor, la segunda fase de utilización del Dolmen de las Casas de Don Pedro o Sierra Palacios III, Agudelo I y II o Sierra Palacios IV y V, Fuente del Corcho o Sierra Palacios VI, Los Prados o Sierra Palacios VII y Cortijo Viejo o Sierra Palacios VIII (Mapa 3, A). Incluimos dentro de la necrópolis de Sierra Palacios I también el enterramiento con ajuar campaniforme localizado en La Retuerta (Fig. 10) (Benito, 1976), practicado en una covacha que se abre en un pequeño farallón que finaliza en el Fresnedoso (Mapa 3, n. ${ }^{\circ} 32$ ).

- Casas de Don Pedro: Por el momento, el hábitat cuyos materiales arrojan la cronología más antigua es el documentado en los terrenos sobre los que se erige el Dolmen de las Casas de Don Pedro (Mapa 1, n. ${ }^{\circ}$ 9). Como hemos indicado, esta sepultura megalítica ha sido objeto de dos campañas de excavación, la primera en 1986, dirigida por quien suscribe (Gavilán, 1987; Gavilán et alii, 1989; Gavilán y Vera, 1994), que vino motivada por la destrucción de parte del túmulo y el desplazamiento de los bloques que formaban la cubierta de la cámara funeraria ante la puesta en riego de los terrenos sobre los que se ubica; y la segunda por nosotros y Vera (Gavilán y Vera, 2001, 2005). En la primera de ellas se acometió la excavación de la cámara funeraria, practicándose una zanja al exterior que puso de manifiesto la posible existencia de una ocupación anterior a la construcción del dolmen. Durante la segunda campaña se excavaron el corredor del dolmen y una amplia cuadrícula de $105 \mathrm{~m}^{2}$ que circundaba todo el espacio funerario. La sucesión estratigráfica al exterior de la estructura megalítica funeraria es la que sigue:

- Tierra beige, muy arcillosa, que formaba el túmulo hasta una profundidad media de $-218 \mathrm{~cm}$. Los restos materiales se reducían a algunos fragmentos de cerámica.

- Arenas amarillentas, estériles, de una potencia media de unos $30 \mathrm{~cm}$., que se entregaban a los ortostatos que forman la estructura funeraria.

- Tierra anaranjada, muy granulosa, cortada por las zanjas de inserción de los ortostatos de la estructura funeraria, habiéndose depositado, por tanto, con anterioridad a la construcción de la cámara. Este nivel permitió documentar las técnicas constructivas de la sepultura megalítica y, además, proporcionó unos datos sumamente interesantes que ponen de manifiesto una ocupación anterior a la construcción de aquella, evidenciada a través de estructuras y artefactos. 

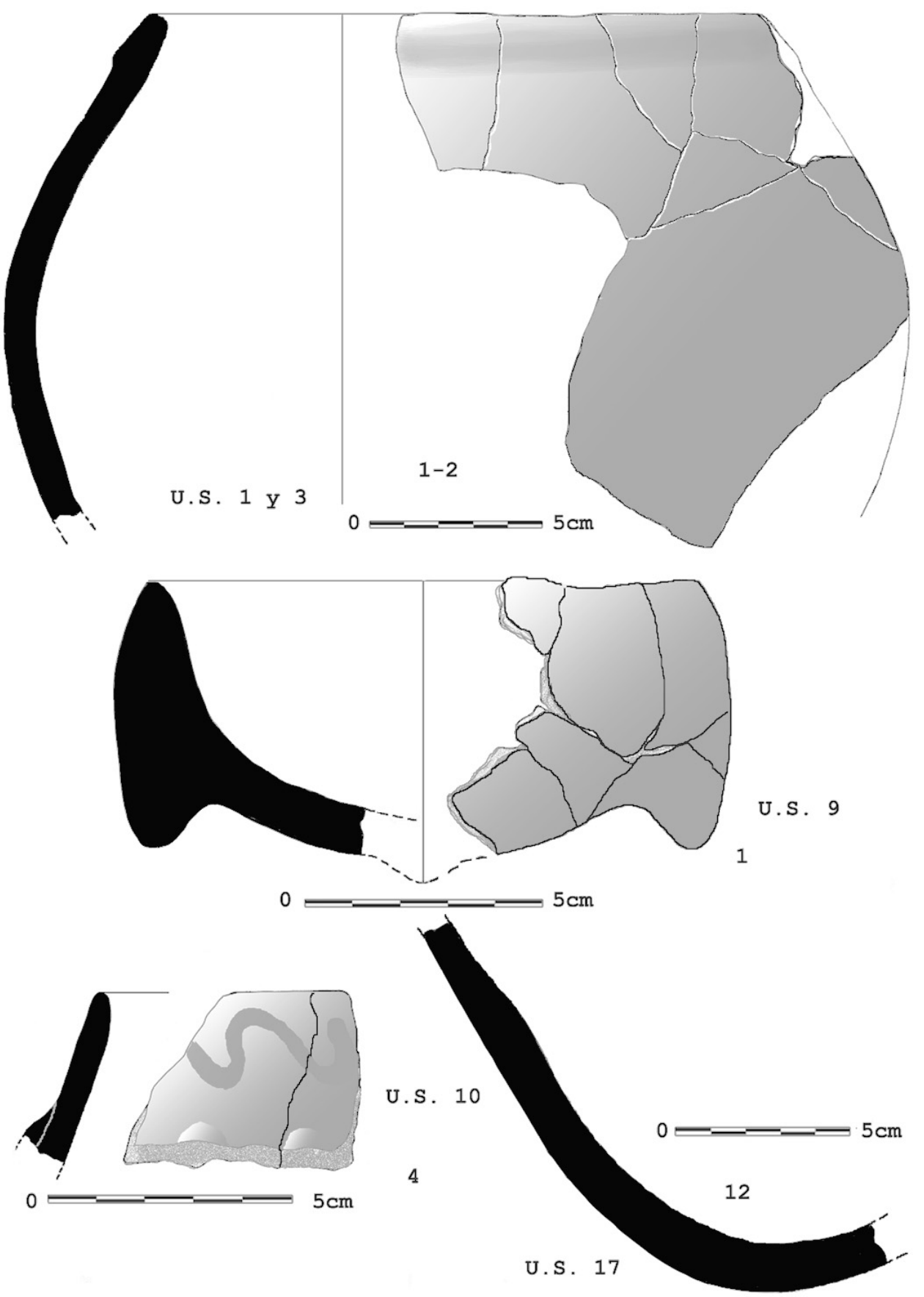

Fig. 7. Casas de Don Pedro. Cerámicas a la almagra y no decoradas. 

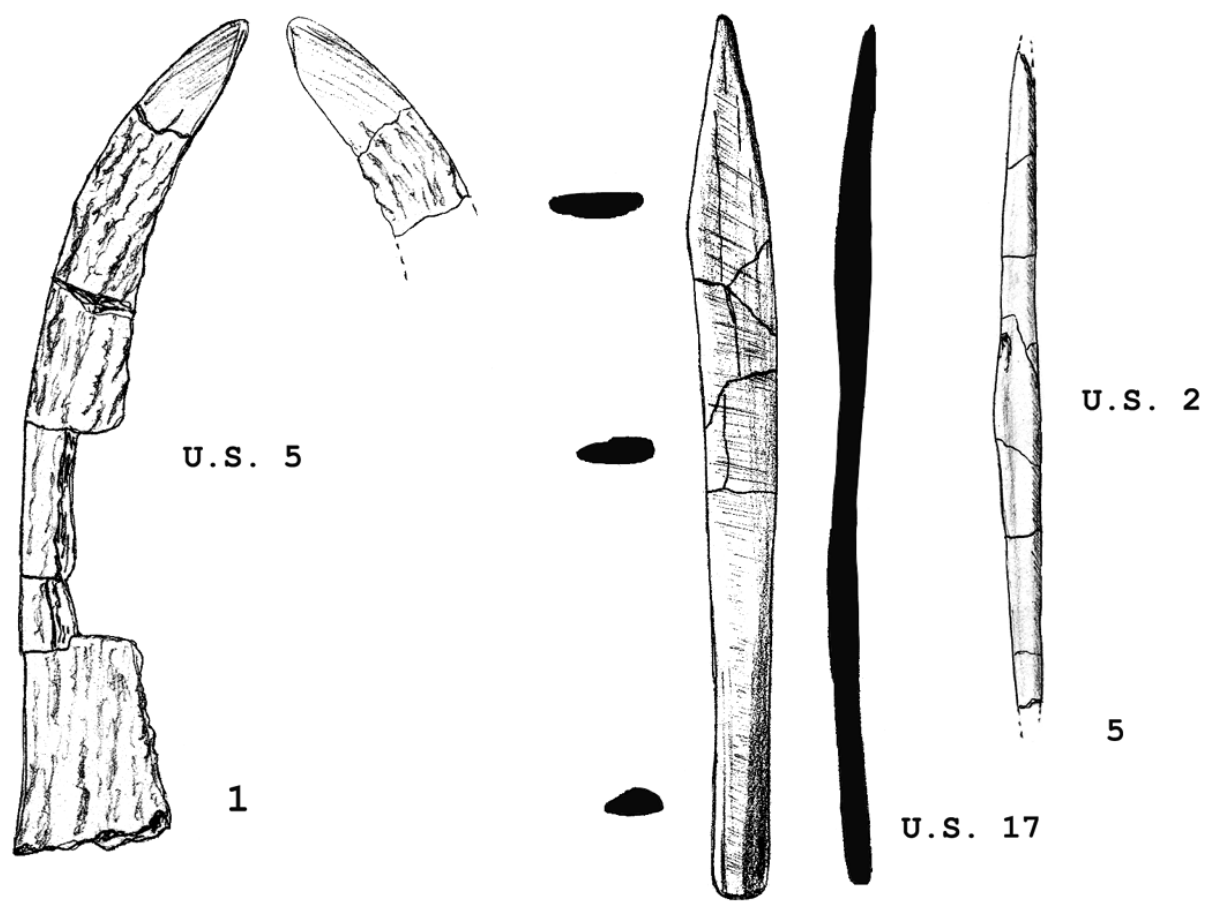

$13-14$
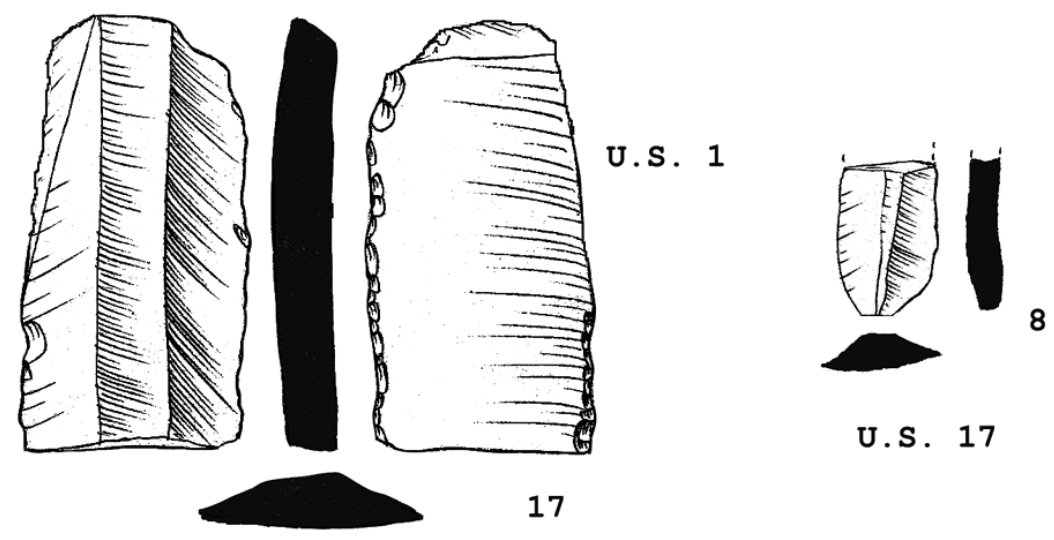

U.S. 17

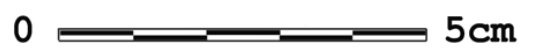

Fig. 8. Casas de Don Pedro. Industrias ósea y lítica. 

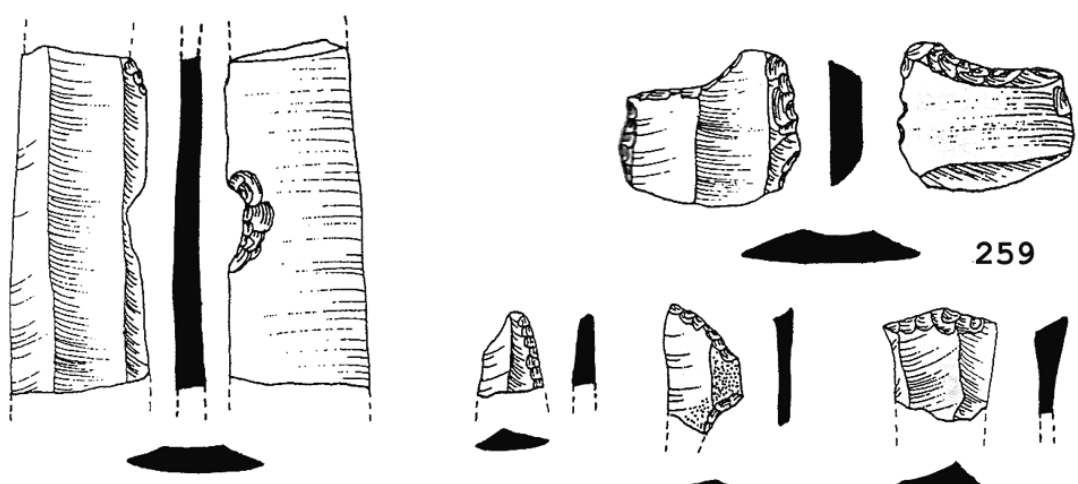

95
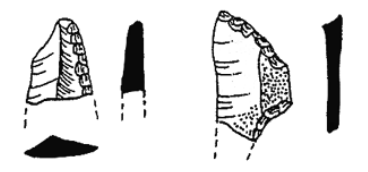

172
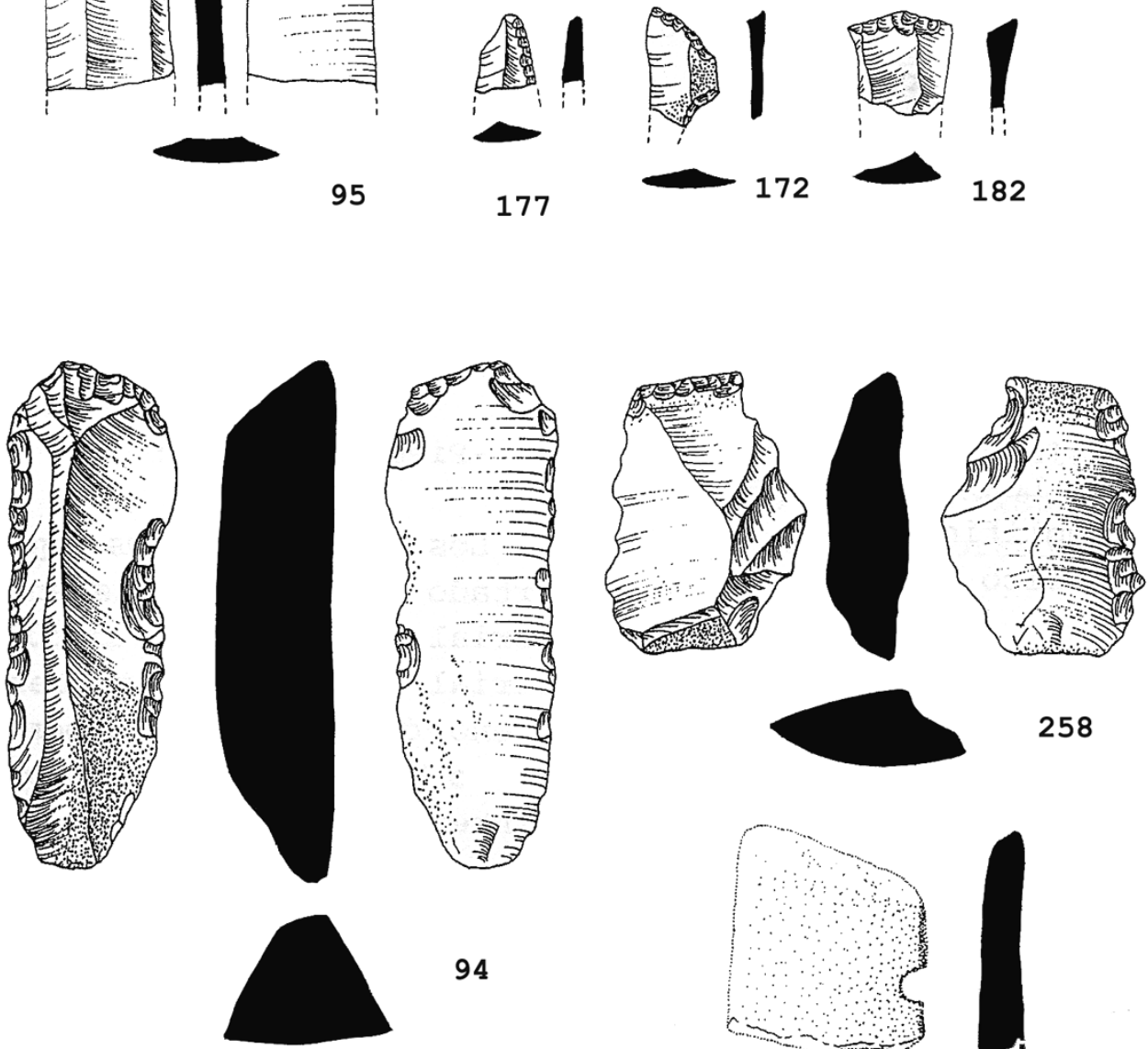

94

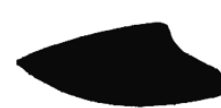

258

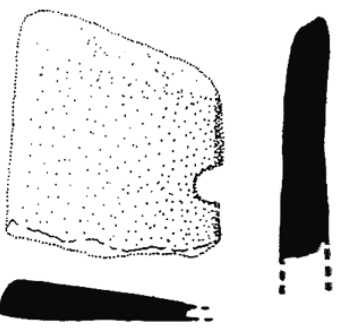

93

0

$5 \mathrm{~cm}$

Fig. 9. Dolmen de las Casas de Don Pedro. Industria lítica. 
A juzgar por los restos materiales, la ocupación de este asentamiento se inicia a mediados-finales del $V$ milenio a.C., siendo frecuentes las cerámicas no decoradas y a la almagra de excelente calidad pero rara vez asociadas a otras decoraciones. Las formas son fundamentalmente globulares de media o tres cuartos de esfera (Fig. 7). Por su parte, los artefactos en asta y en hueso también están presentes (Fig. 8), así como la industria lítica tallada, destacando las hojas y lascas retocadas o sin retocar, fracturas retocadas, un trapecio, un perforador, un raspador y un elemento de hoz (Fig. 9), algún núcleo y chunks, junto con restos de talla; finalmente, contamos con un elemento de molturación, piedras exógenas y numerosos trozos de hematites.

En cuanto a las estructuras, se documentaron varias fosas y hogares. Entre las fosas, una de ellas, de reducido tamaño, estaba cortada por una de las zanjas de inserción de los ortostatos que posteriormente dieron cuerpo a la cámara funeraria, otra, de amplias dimensiones, contenía en su interior un acumulo de hematites, presentando varios de ellos señales de abrasión, un elemento de molturación e industrias ósea y lítica.

Los tres hogares detectados se encontraban en línea recta y equidistantes, y aunque todos mostraban mezcla de carbones y colorante (posiblemente hematites o cinabrio), el mayor de ellos, localizado en la zona oeste y cercano a la fosa de dimensiones más amplias, contenía una cantidad superior de colorante y estaba asociado a manchas carbonosas de una plasticidad tan elevada que sugiere una clara intencionalidad.

Asimismo interesante fue la documentación de un pavimento, de unos $4 \mathrm{~cm}$. de potencia, hecho a base de hematites triturada y mezclada con algún aglutinante arcilloso. Este suelo no aportó prácticamente restos materiales, encontrándose todo al exterior del mismo, pero su situación resulta muy significativa: En el sector noroeste, ofreciendo una forma ovalada que partía de dos de los ortostatos de cabecera del dolmen, precisamente los dos que por materia lítica - conglomeradoy tratamiento - piqueteado - son diferentes al resto de los que forman la estructura funeraria. Asociados a las antes descritas estructuras, se encontraban cinco agujeros para poste que circundaban el ortostato situado en el ángulo noroeste, el más estrecho de los dos anteriores (Lám. 1).

Por su parte, en el lado sur, al exterior de la cámara, aparecieron varios guijarros de río de buen tamaño que posiblemente formaron parte de estructuras de hábitat desmanteladas.

Cabe destacar, finalmente, que el relleno de las zanjas de inserción de los dos ortostatos de cabecera indicados difiere con respecto a los restantes de la cámara funeraria. En el caso de los primeros, aquellas se rellenaron con la misma tierra, hecho que impidió determinarlas, mientras que en los segundos las zanjas se rellenaron con una arcilla muy compacta y distinta a la del túmulo, facilitando esto la determinación de su exacta forma. 


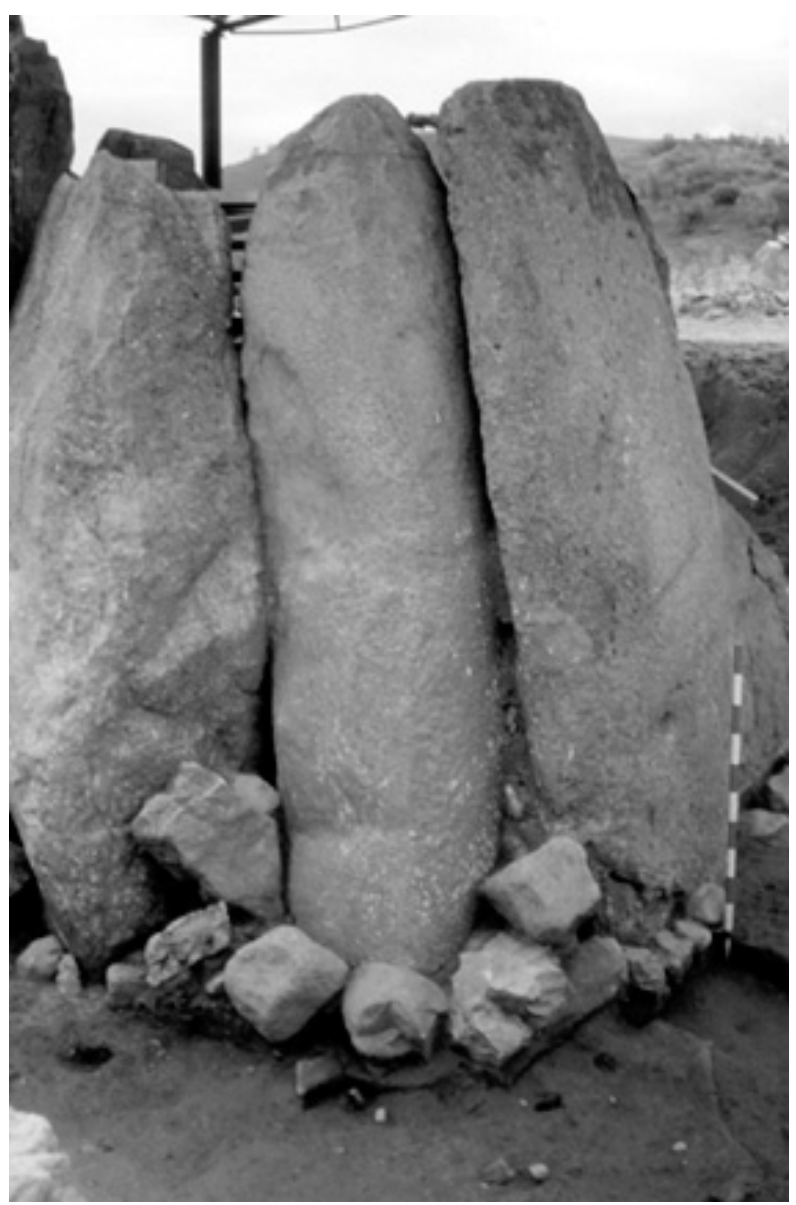

Lám I. Casas de Don Pedro, menhires.

De este modo, la diferencia entre las zanjas de inserción de los ortostatos, el dispar material pétreo elegido para los de cabecera y los restantes, así como la documentación de una ocupación previa, nos ha llevado a defender la existencia de un megalitismo prefunerario (Gavilán y Vera, 2005) a base de menhires, a cuyo amparo y en los momentos finales del Neolítico se erige una cámara funeraria simple mediante la adición de más ortostatos, cámara que posteriormente se dotará de corredor en dos fases ya calcolíticas. Sin embargo no son estos aspectos, sin duda interesantes, los que nos conciernen en este momento, sino la existencia de un asentamiento de singulares características que puede fecharse a finales del $\mathrm{V} \mathrm{mi-}$ lenio a.C. o principios del IV.

- Castillo de Belmez: Se trata de un cerro aislado que se eleva a 616 m.s./n.m. y 120 m. sobre el Guadiato. Se localiza en las coordenadas $38^{\circ} 16^{\prime} 27^{\prime \prime}$ 

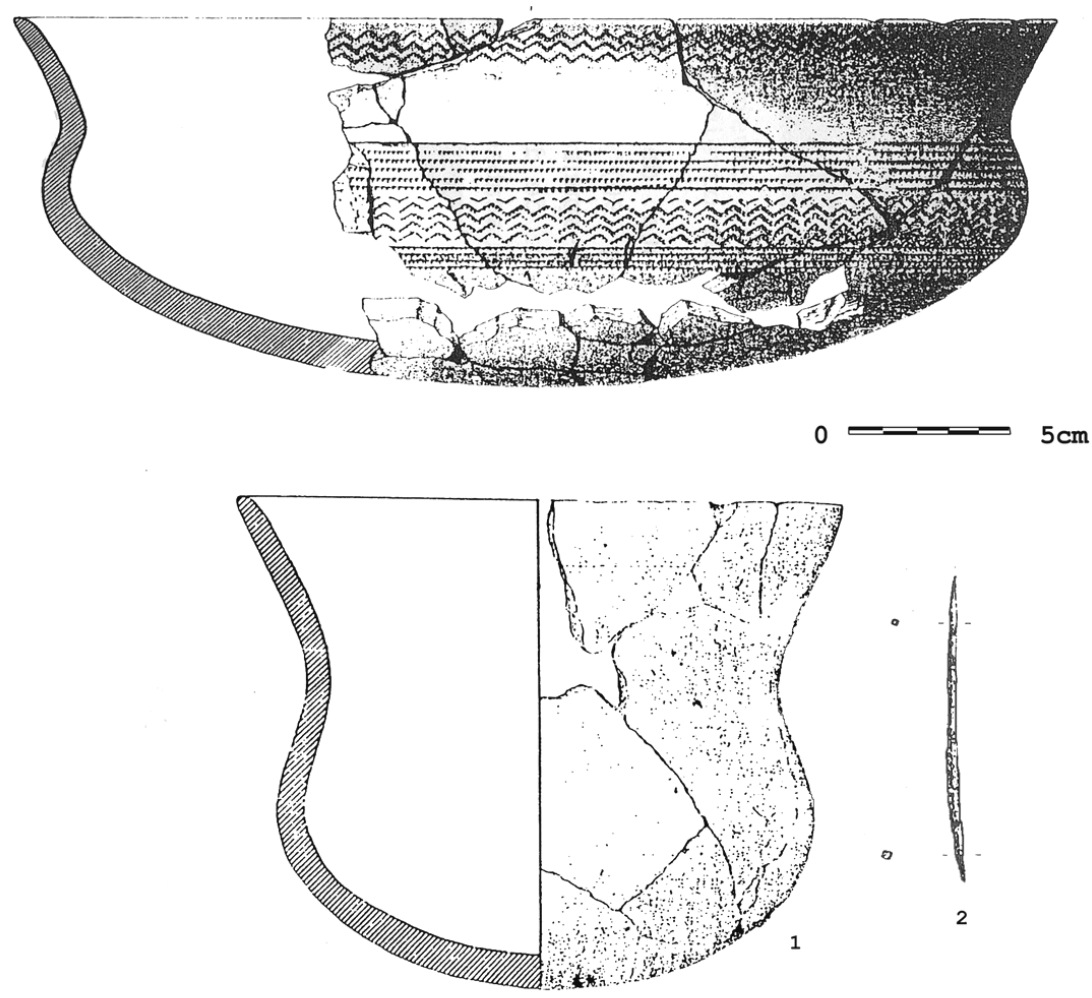

Ajuar de la Retuerta (Según BENITO, 1976)

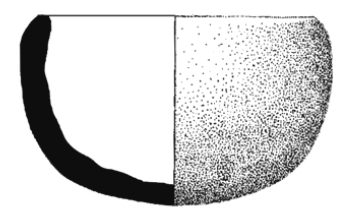

12.439

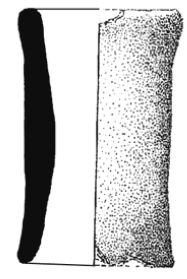

12.441
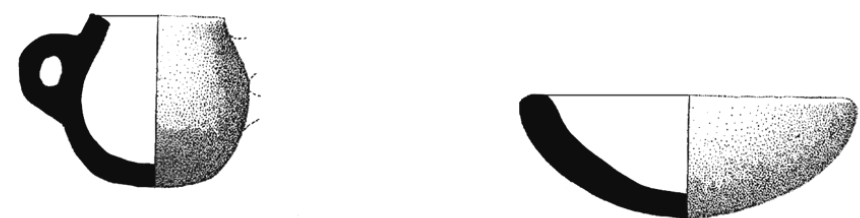

12.438

Castillo de Belmez.

Fig. 10. La Retuerta y Castillo de Belmez. 
norte y $1^{\circ} 31^{\prime} 27^{\prime \prime}$ oeste del M.T.N. E. 1:50.000 (Hoja 879). Se encuentra próximo a Sierra Palacios, del que lo separa una distancia de unos $3 \mathrm{~km}$. (Mapa 3, n. ${ }^{\circ} 10$ ).

$\mathrm{Ha}$ aportado unos restos materiales, rodados y escasos, entre los que destacan los fragmentos de cuencos y de formas globulares, platos de borde engrosado y almendrado, junto a un hacha, piezas activas y pasivas de molino y piezas líticas talladas, en sílex y cuarcita. La adscripción que propusimos (Gavilán y Vera, 1989-90), Calcolítico Pleno, sigue siendo válida, ya que se desconocen, por el momento, restos materiales anteriores y/o posteriores.

En la base del Cerro del Castillo de Belmez fue localizado, a mediados del pasado siglo, un ajuar funerario constituido por varios cuencos y un soporte que fueron dados a conocer por Samuel de los Santos (1958) como procedentes de un sepulcro (Fig. 10). Ante la parquedad de la noticia sobre la ubicación de este ajuar, Vera (1999) indica que el enterramiento pudo realizarse en una de las covachas existentes en la ladera del cerro.

- El Peñón: Situado a 775 m.s./n.m. y a unos 220 sobre el nivel del Río Guadiato, se localiza en las coordenadas $38^{\circ} 19^{\prime} 10^{\prime \prime}$ norte y $1^{\circ} 36^{\prime} 00^{\prime \prime}$ oeste del M.T.N. E. 1:50.000 (Hoja 879) (Mapa 4, n. ${ }^{\circ}$ 11). Este asentamiento fue estudiado por Murillo (1986 a) y Vera (1999). Junto con Sierra Palacios y La Calaveruela, se trata de uno de los asentamientos de mayor entidad conocidos en la zona.

Destacan las puntas de flecha, dientes de hoz, taladros, geométricos, escotaduras, hojas y núcleos. Dentro del conjunto cerámico hay que citar las decoraciones a base de incisiones e impresiones, pero descuellan los abundantes platos de borde engrosado y almendrado, cuencos, cerámicas de formas globulares, vasijas carenadas y de perfiles acampanados, así como fragmentos de campaniforme inciso, queseras y cuernecillos. Están bien representadas las hachas, azuelas y piezas activas y pasivas de molino. La metalurgia está documentada mediante la presencia de gotas de metal, un fragmento de crisol con restos de cobre y un fragmento de hacha, otro de punta, leznas y un cincel, además de fragmentos no identificables.

A partir de los mencionados restos, el asentamiento ha sido adjudicado al Calcolítico, desde su plenitud a los momentos finales, aunque las cerámicas de carena media y la acampanada permiten plantear un hábitat más prolongado en el tiempo (Gavilán y Vera, 1989-90; Vera, 1999).

- Cerro Masatrigo: Ubicado junto al arroyo de San Pedro, se trata de un auténtico cerro testigo que se localiza en las coordenadas $38^{\circ} 17^{\prime} 33^{\prime \prime}$ norte y $1^{\circ} 39^{\prime} 7^{\prime \prime}$ oeste del M.T.N. E. 1: 50.000 (Hoja 879), a 556 m.s./n.m. (Mapa 3, n. ${ }^{\circ} 12$ ). Se encuentra cerca de Las Calerillas, a unos $2,8 \mathrm{~km}$.

El exiguo repertorio de material está constituido por fragmentos de platos de borde engrosado, atípicos, un hacha pulimentada y puntas de flecha, que apuntan hacia el Calcolítico, sin más posibilidades de precisión (Gavilán y Vera, 1989-90). 
- El Calvario o La Granjuela I: A corta distancia del núcleo de población de La Granjuela, se encuentra a 565 m.s./n.m., en una zona llana aunque de ligera inclinación. Se localiza en las coordenadas $38^{\circ} 22^{\prime} 26^{\prime \prime}$ norte y $5^{\circ} 20^{\prime} 30^{\prime \prime}$ oeste del M.T.N. E. 1:50.000 (Hoja 857). Dista del Cerro del Castaño unos 3,5 km. (Mapas 2 y $\left.3, n .{ }^{\circ} 13\right)$.

Dado a conocer por Vera (1999), cuenta con cazuelas carenadas y platos de borde engrosado en semejante proporción, vasijas globulares, "queseras», así como fragmentos de campaniforme, plaquetas de arcilla; hachas y elementos relacionados con la molturación; para la industria lítica tallada se emplearon el cuarzo, la cuarcita y el sílex, materias en las que se fabricaron puntas de flecha, hojas y lascas, hojas de dorso doble, restos de talla. Destaca un fragmento de «ídolo».

Vera adjudica el inicio de esta ocupación en el tránsito Calcolítico Inicial-Pleno (1999), sin embargo, atendiendo a los restos materiales, consideramos que el hábitat debió iniciarse en el Calcolítico Inicial, indicando los campaniformes una ocupación más dilatada en el tiempo, pero sin que podamos precisar, al tratarse de recogida superficial, si hubo o no continuidad en el hábitat durante la plenitud del período.

- Las Calerillas: Situado sobre una terraza fluvial, se trata de un asentamiento en llano ubicado casi en la confluencia de los arroyos Montuenga y Calerillas con el de San Pedro. Se localiza en las coordenadas $1^{\circ} 39^{\prime} 45^{\prime \prime}$ norte y $38^{\circ} 17^{\prime}$ 48" oeste del M.T.N. E. 1:50.000 (Hoja 879), a 520 m.s./n.m. (Mapa 1, n. ${ }^{\circ} 14$ ).

Ha proporcionado cazuelas carenadas, platos de borde engrosado -más abundantes las primeras-, cuencos, formas globulares de tres cuartos de esfera, fragmentos decorados a la almagra de escasa calidad; restos de adobe con improntas de cañizo y plaquetas de arcilla perforadas. Las hachas, azuelas y piezas activas y pasivas de molino son significativas, mientras que la industria lítica cuenta sólo con lascas y restos de talla, cuya pobreza opinamos obedece a las circunstancias de la recogida.

Es un asentamiento muy semejante al de Los Delgados, y para el que propusimos una misma adjudicación cultural (Gavilán y Vera, 1989-90) que, como en el caso anterior, retrotraemos a la transición Neolítico-Calcolítico.

- Cerro del Castaño: Situado en la margen izquierda del Guadiato, este asentamiento, también en ladera, se localiza en las coordenadas $38^{\circ} 15^{\prime} 20^{\prime \prime}$ norte y $1^{\circ} 40^{\prime} 25$ " oeste del M.T.N. E. 1:50.000 (Hoja 879), a unos 560 m.s./n.m y entre 20-30 sobre el río, controlando un vado de éste (Mapa 1, n. ${ }^{\circ} 15$ ).

Son escasos los restos materiales aportados: Un fragmento de cazuela carenada, fragmentos de cuencos de media y tres cuartos de esfera, junto con lascas, restos de talla y una hoja de dorso, además de improntas de cañizos. Adjudicado al Calcolítico Inicial (Gavilán y Vera, 1989-90), la ausencia de platos de borde engrosado y otros elementos comunes en el citado período, nos lleva a proponer un 
cambio de adscripción, planteando que este hábitat pudo estar ocupado durante el Neolítico Tardío o Final, pero siendo conscientes de que la escasa cantidad de materiales que ha proporcionado dificulta su adscripción, y la que aquí proponemos puede modificarse ante la constatación de hallazgos futuros.

- Los Castillejos de Fuente-Obejuna: Como la mayoría de los asentamientos calcolíticos de la zona se encuentra en un cerro testigo, que se eleva a 591 m.n./n.m. Sus coordenadas son: $38^{\circ} 17^{\prime} 10^{\prime \prime}$ norte y $1^{\circ} 41^{\prime} 10^{\prime \prime}$ oeste, del M.T.N. E. 1:50.000 (Hoja 879) (Mapa 3, n. ${ }^{\circ} 16$ ).

Excavado en parte por Blázquez (1981) con motivo de su intervención en la Mina de la Loba, este asentamiento ha aportado también restos procedentes de recogidas superficiales, contándose con platos de borde engrosado, cuencos de media esfera, vasijas globulares y con cuello, fragmentos de campaniforme impreso; fragmentos de queseras, una fusaiola y numerosos cuernecillos, junto con algunos adobes con improntas de cañizo. Son muy abundantes las puntas de flecha, estando presentes las hojas, lascas, restos de talla y de núcleos. Hachas, azuelas y un martillo de minero, una sierra de cobre, fragmentos de leznas y uno de punta, así como una cuenta de collar y un ídolo falange completan el material.

La adjudicación propuesta para este asentamiento responde a un momento avanzado de la plenitud del Calcolítico y a la fase final (Gavilán y Vera, 1989-90; Vera, 1999).

- Los Castillejos de La Granjuela: Se localiza en las coordenadas $38^{\circ} 23^{\prime} 26^{\prime \prime}$ norte y $5^{\circ} 20^{\prime} 30^{\prime \prime}$ oeste, del M.T.N. E. 1:50.000 (Hoja 879). Este hábitat se emplazó sobre una zona amesetada, a unos 622 m.s./n.m., en la divisoria de los cursos fluviales Zújar y Guadiato (Mapas 2 y 3, n. ${ }^{0} 17$ ). Ha sido estudiado por Vera (1999), quien indica la existencia de una línea de fortificación que protege el asentamiento por sus flancos sur y este.

Sobresalen las puntas de flecha y los elementos de hoz, junto con lascas retocadas y láminas y lascas sin retoque, restos de talla y núcleos. Las hachas, azuelas y piezas activas y pasivas de molino están muy bien representadas. El conjunto cerámico consta de escasas cazuelas carenadas, numerosos platos de borde engrosado y almendrado, además de cuencos, formas globulares con cuello marcado, formas carenadas y de perfil en «S", grandes contenedores, "Ollas", entre otras. Están presentes las cerámicas decoradas, que se reducen almagras, de baja calidad, a un fragmento de cerámica impresa, y, finalmente, a otros de campaniforme, uno impreso y tres incisos. Placas de arcilla, cuernecillos y adobes con improntas de cañizo, algunos con evidencias de haberse quemado, completan este apartado.

En adorno destaca la única pieza recuperada. Por último, cabe subrayar que la presencia de escorias de fundición pone de manifiesto la actividad metalúrgica.

Teniendo en cuenta los anteriores restos, y dejando de lado el colgante de cornalina, Vera (1999) plantea que la vida de este emplazamiento debió comenzar en 
el Calcolítico Pleno, continuando durante la fase final del período. La presencia ya de platos de borde engrosado en buena cantidad, aunque aún continuan las cazuelas carenadas, nos inclina a proponer el comienzo de esta ocupación en el Calcolítico Inicial, prolongándose a lo largo del Pleno y Final. Por último, destaca un colgante de cornalina de procedencia extrapeninsular que nos situa en momentos más avanzados, pero nada más hay entre los restos materiales recuperados que asegure la continuidad del hábitat hasta el I milenio a.C. (Vera, 1999; Martín et alii, 2006).

- La Cinta: Se localiza en las coordenadas $38^{\circ} 28^{\prime} 23^{\prime \prime}$ norte y $5^{\circ} 22^{\prime} 35^{\prime \prime}$ oeste, del M.T.N. E. 1:50.000 (Hoja 857); se encuentra a 760 m.s./n.m., sobre una meseta que se eleva a unos $180 \mathrm{~m}$ sobre el valle perteneciente a la cuenca del Zújar (Mapas 2 y 3, n. ${ }^{\circ} 18$ ). Se trata, por tanto, de un asentamiento en altura.

Los restos materiales aportados hasta el momento son escasos, destacando las puntas de flecha y restos de talla, algunas cazuelas carenadas, platos de borde engrosado y un fragmento de cerámica campaniforme impreso; un molino y un fragmento de azuela completan la ergología que, aunque escasa, parece, en principio, suficiente para proponer una adscripción cultural correspondiente a los momentos finales del Calcolítico Inicial, alcanzando la ocupación hasta el final del período, si bien Vera (1999) adjudica este hábitat a las fases plena y final del Calcolítico.

- Cerro de las Piedras: Se localiza en las coordenadas $38^{\circ} 12^{\prime} 25^{\prime \prime}$ y $1^{\circ} 43^{\prime}$ 55" del M.T.N. E. 1:50.000 (Hoja 879), sobre un cerro de de considerables dimensiones (Mapa 3, n. ${ }^{\circ}$ 19).

Los restos materiales destacan por la total ausencia de cazuelas carenadas, siendo abundantes y variados los platos de borde engrosado, cuencos hemisféricos y de tres cuartos de esfera, grandes vasijas globulares y cilíndricas, en lo que a cerámica no decorada se refiere. La decorada consta de fragmentos impresos, incisos, uno acanalado, y varios fragmentos campaniformes (Vaquerizo et alii, 1994). Por su parte, son numerosas las puntas de flecha de tipología variada, láminas retocadas y un perforador; están presentes las hachas, las azuelas y dos martillos de minero. Por último, cabe destacar la presencia de un punzón de cobre $y$ tres puntas de Palmella.

Culturalmente, el asentamiento ha sido adjudicado a los momentos plenos del Calcolítico (Vera, 1999), continuando el hábitat durante el final del período, adjudicación que nos parece debe seguir manteniéndose.

A este poblado hemos atribuido la necrópolis dolménica del Los Pozos-Obatón (Gavilán y Vera, 1994) (Mapa 3, C), que incluye Zampatortas o Pozos III, Pozos I y Pozos I, así como Obatón I a IV, situados a unos $3,5 \mathrm{~km}$ al noroeste del poblado; más alejado se encuentra el túmulo de Los Pánchez, situado a algo menos de 5 $\mathrm{kms}$ al sureste (Mapa 3, n. ${ }^{\circ} 33$ ). 
- Los Delgados: Está situado en la finca del mismo nombre, en las coordenadas $38^{\circ} 13^{\prime} 30^{\prime \prime}$ norte y $1^{\circ} 47^{\prime} 20^{\prime \prime}$ oeste del M.T.N. E. 1:50.000 (Hoja 879) (Mapa 2, n. ${ }^{\circ} 20$ ). Muy próximo al nacimiento del río Guadiato, se encuentra en una zona llana.

Las cazuelas carenadas y los platos de borde engrosado, éstos más abundantes, son los recipientes cerámicos más representativos, habiendo proporcionado también fragmentos de cuencos, formas globulares y cerámicas decoradas con una ligera capa de almagra. Además de cuernecillos y plaquetas de arcilla, se cuenta con hachas, azuelas y piezas activas y pasivas de molino, así como con un taladro de sílex y hojas retocadas.

Durante la prospección realizada pudimos observar pequeños círculos de tierra oscura, puestos al descubierto por las actuales labores agrícolas, que interpretamos como fondos de cabaña, en cuyo interior aparecían abundantes adobes, afectados por combustión, y otros restos.

En una publicación anterior (Gavilán y Vera, 1989-90) adjudicamos este asentamiento al Calcolítico Inicial y Pleno, sin embargo, según el criterio expuesto en el apartado anterior, la presencia de cazuelas carenadas en una proporción elevada, aunque dominando ya los platos de borde engrosado, nos lleva a plantear que la ocupación de este asentamiento tiene lugar el Calcolítico inicial.

No queremos dejar de mencionar que el Dolmen de Los Delgados II se encuentra sobre los terrenos en los que se localiza el asentamiento, sin embargo, teniendo en cuenta los materiales aportados por el hábitat que nos ocupa y los procedentes del sepulcro —-más recientes_, resulta problemático plantear que éste se construyera durante el tiempo de vida del asentamiento, habiendo defendido que este dolmen debe adjudicarse al poblado de La Calaveruela, de mayor entidad y con una ergología que permite su encuadre (Gavilán y Vera, 1994).

- La Calaveruela: Se localiza en las coordenadas $38^{\circ} 13^{\prime} 40^{\prime \prime}$ norte y $1^{\circ} 49^{\prime}$ 20" oeste del M.T.N. E. 1:50.000 (Hoja 879). Este cerro asilado, de 732 m.s./n.m., forma la divisoria de aguas entre los ríos Zújar y Guadiato, encontrándose a unos 50 m de elevación sobre este río y a 400 m de distancia de su nacimiento (Mapa 3 , n. $\left.{ }^{\circ} 21\right)$.

Entre los restos materiales que ha proporcionado se cuentan numerosos platos de borde engrosado, cuencos semiesféricos y de tres cuartos de esfera, un fragmento de cazuela carenada, cinco fragmentos de campaniforme, plaquetas y cuernecillos en lo que al conjunto cerámico se refiere; están presentes las hachas, azuelas y los elementos de molturación. Por su parte, la industria lítica tallada es variada, destacando las puntas de flecha, algunas con aletas, hojas de dorso, elementos de hoz y largas hojas retocadas, así como algún raspador, perforador y un buril. Finalmente, una cuenta de collar cilíndrica completa la ergología. Como materiales de construcción cabe destacar abundantes restos de adobes con improntas de cañizo. 
Estos restos permiten una adscripción correspondiente al Calcolítico Pleno (Gavilán y Vera, 1989-90; Vera, 1999). Sin duda, se trata de uno de los poblados más interesantes del Alto Valle del Guadiato. Su situación resulta extremadamente estratégica y está rodeado de buenas tierras de labor y de amplias zonas de pastos; por otra parte, el hecho de ser el único de este sector del valle con entidad suficiente, permite que se le pueda atribuir una necrópolis formada por los dólmenes de la Cardenchosa, en la que se incluyen algunos situados en la actual provincia de Badajoz (Granja de Torrehermosa), a unos $4 \mathrm{~km}$ al oeste, y la constituida por La Sierrezuela y Los Delgados, situada a $3 \mathrm{~km}$ al este de La Calaveruela (Cabrero, 1988 b; Gavilán y Vera, 1994; Vera, 1999) (Mapa 3, B). Esta última la integran los sepulcros de El Gigante o Gallegos I, La Horma, Sierrezuela I a III, y Los Delgados I a IV, tratándose de una necrópolis en la que están presentes diferentes técnicas arquitectónicas, desde los dólmenes ortostáticos, dólmenes a base de lajas de pizarra de pequeño tamaño, y los tholoi de falsa cúpula.

\section{ENCUADRE CRONOCULTURAL}

Somos conscientes de que al tratarse en la mayoría de los casos de materiales procedentes de recogidas superficiales -excepción hecha de Sierra Palacios, el hábitat previo a la erección del Dolmen de las Casas de Don Pedro, esta sepultura y el Dolmen de la Fuente del Corcho y, quizá, Los Castillejos de Fuente Obejuna-, la valoración que proponemos puede verse modificada en el futuro, bien debido a la presencia de restos más antiguos y/o recientes, bien a la excavación de alguno de los hábitats. Sin embargo, pese al obstáculo que supone la falta de dataciones absolutas y la escasez de secuencias, los datos y el número de yacimientos con que contamos son suficientes para plantear una evolución del poblamiento en el Alto Valle del Guadiato, trabajo que ya abordamos (Gavilán y Vera, 1989-90), pero que ahora matizamos en función de nuevos registros y de los resultados aportados por otros contextos estratigráficos procedentes de yacimientos situados en diferentes sectores andaluces.

De este modo, adjudicamos al Neolítico Antiguo/Medio -Finales del $\mathrm{V}$ milenio a.C. a mediados del IV-, Cueva Agustín y el asentamiento previo al Dolmen de las Casas de Don Pedro; al Neolítico Tardío —-mediados/finales del IV milenio a.C. a comienzos del III-Sierra Palacios II y, posiblemente, el Cerro del Castaño.

En el tránsito entre el Neolítico/Calcolítico —últimos siglos del primer cuarto del III milenio a.C.- incluimos Las Calerillas a tenor de la mayor representación de cazuelas carenadas con respecto a los platos de borde engrosado.

Por su parte, la ocupación de El Calvario o La Granjuela I y Los Delgados pudieron comenzar en los umbrales del Calcolítico Inicial — segundo cuarto del III milenio a.C. - si tenemos en cuenta que en el primero de ellos la proporción de cazuelas y platos está equilibrada, y en el caso del segundo dominan ya los platos de 
borde engrosado. En lo que respecta al primer asentamiento, teniendo en cuenta la presencia de restos de cronología más avanzada y su proximidad a Los Castillejos de La Granjuela, coincidimos con Vera (1999) en que su ocupación pudo ser discontinua, sobre todo durante la fase plena, reocupándose durante el Calcolítico Final en función de la explotación de las tierras cultivables.

Aunque con menor presencia de cazuelas carenadas, los hábitats de Huerta del Caño, Los Castillejos de La Granjuela y la Cinta, comienzan en el Calcolítico Inicial, mientras que resulta algo problemático plantear sin menoscabo de duda que el asentamiento de Sierra Palacios I comenzara a partir de esta primera fase del período, hipótesis muy sugerente, como señalamos más adelante.

Al Calcolítico Pleno - segunda mitad del III milenio a.C.- corresponde la mayor parte de los asentamientos documentados, incluyendo en esta fase Sierra Palacios I, La Cornuda, Cerro del Ermitaño, Castillo de Belmez, El Peñón, Los Castillejos de Fuente-Obejuna, La Cinta, Cerro de las Piedras y La Calaveruela. Fase también presente en Huerta del Caño y Los Castillejos de la Granjuela.

Materiales correspondientes al Calcolítico Final —finales del III milenio a.C. y comienzos del II- se han documentado en los asentamientos en los que está presente la fase plena, excepción hecha de Huerta del Caño, Cerro de Las Piedras y Castillo de Belmez.

Para los asentamientos de La Lozana, Cerro del Molino y Cerro Masatrigo únicamente señalamos su pertenencia al Calcolítico, manteniendo lo propuesto en otros trabajos (Gavilán y Vera, 1989-90) para el caso de Masatrigo, y coincidiendo con otros autores (Vera, 1999) para La Lozana y Cerro del Molino.

Además de los sepulcros megalíticos, túmulos y covachas que hemos mencionado al tratar sobre los asentamientos, contamos con otros túmulos y dólmenes que no podemos asociar con claridad a un hábitat por la distancia implicada. Dos de ellos se encuentran a escasos metros de la margen derecha del Guadiato, uno en el embalse de Sierra Boyera y otro en el del Pantano de Puente Nuevo (Mapa 3, n. ${ }^{\circ}$ 31 y 25 respectivamente); ya alejados del citado río están el de Los Pánchez (Mapa 3, n. ${ }^{\circ}$ 33) y los de Doña Rama I y II (Mapa 3, n. ${ }^{\circ} 29$ y 30), estos últimos, aunque algo alejados, quizá pudieron formar parte de la Necrópolis de Sierra Palacios.

\section{CONSIDERACIONES FINALES}

Expuestos, si bien escuetamente, los hábitats que se conocen en el Alto Valle del Guadiato, es momento ya de atender al desarrollo del poblamiento en el mismo durante el Neolítico y el Calcolítico. Previamente, queremos dejar constancia, nuevamente, de que resulta de todo punto imposible descartar ocupaciones bifásicas en bastante de los hábitats, y que el planteamiento que presentamos debe entenderse únicamente como una aproximación. 
Planteamos, de este modo, una ocupación ex novo de este sector por parte de sociedades productoras, ya que sólo se conoce una estación adjudicada al Epipaleolítico, insuficiente para sugerir una relación y/o continuidad que indiquen un desarrollo local que, por otra parte, habría que entender como fruto del contacto con grupos productores procedentes de otros sectores provinciales y/o regionales. Al respecto debe tenerse en cuenta la Cueva del Cañaveralejo, en Adamuz, (Gavilán, 1986 c), situada en la zona oriental de la Sierra Morena cordobesa, o la Cueva Chica de Santiago (Cazalla de la Sierra) (Acosta, 1986), en la provincia de Sevilla.

Así, pues, a tenor de los datos con que contamos hasta el presente, actualmente los testimonios más antiguos referidos al establecimiento en la zona de las primeras sociedades productoras remiten a Cueva de Agustín (Gavilán y Vera, 1989-90) y al asentamiento de las Casas de Don Pedro (Mapa 1), que se remontan a finales del $\mathrm{V}$ o principios del IV milenios a.C.

De la ocupación del primero poco podemos apuntar ante la escasez del material y el carácter del hallazgo, efectuado hace ya bastantes años con motivo de la explotación de la caliza del sector noroccidental del conjunto de Sierra Palacios.

Con respecto al segundo, y como hemos expresado en otro trabajo (Gavilán y Vera, 2005), se trata de un asentamiento de especial significado, interpretando la erección de estos menhires como reflejo del cambio de mentalidad directamente relacionado con la economía productora, expresándose y simbolizándose mediante ellos el derecho a la propiedad y explotación del territorio al encontrarse muy próximos a una vía natural de comunicación, el Fresnedoso, en su confluencia, en un vado, con el Guadiato, principal curso fluvial del sector noroccidental de la provincia de Córdoba. A esta función de marcador territorial cabe sumar, perfectamente, un carácter sagrado ante las evidencias documentadas - suelo rojo y hogares-, celebrándose en torno a ellos determinados rituales que redundarían en el derecho a la posesión y explotación del territorio, al tener éste una importancia crucial para garantizar la reproducción económica y social. Por otra parte, debemos destacar el hecho, no menos importante, de que en un momento que no podemos precisar del Neolítico Final, la estructura megalítica prefuneraria pasa a convertirse en cámara simple para acoger los restos óseos correspondientes a dos individuos. Al sepulcro se le añadirá posteriormente el corredor, enterrándose en la cámara un tercer individuo acompañado de un ajuar metálico (Fig. 11), correspondiente ya al Calcolítico. Estos hechos avalan, entre otros, el carácter simbólico y de hito territorial de este lugar.

La cuadrícula abierta resultó insuficiente para poder determinar si los menhires y las estructuras que se le asocian formaban parte de un asentamiento más amplio, posibilidad que no hay que descartar si se interpretan los grandes guijarros documentados en la zona suroeste como pertenecientes a estructuras de hábitats desmanteladas, si bien no se localizaron otros elementos constructivos, como pueden ser adobes con improntas de cañizo; o bien este espacio estaba destinado 

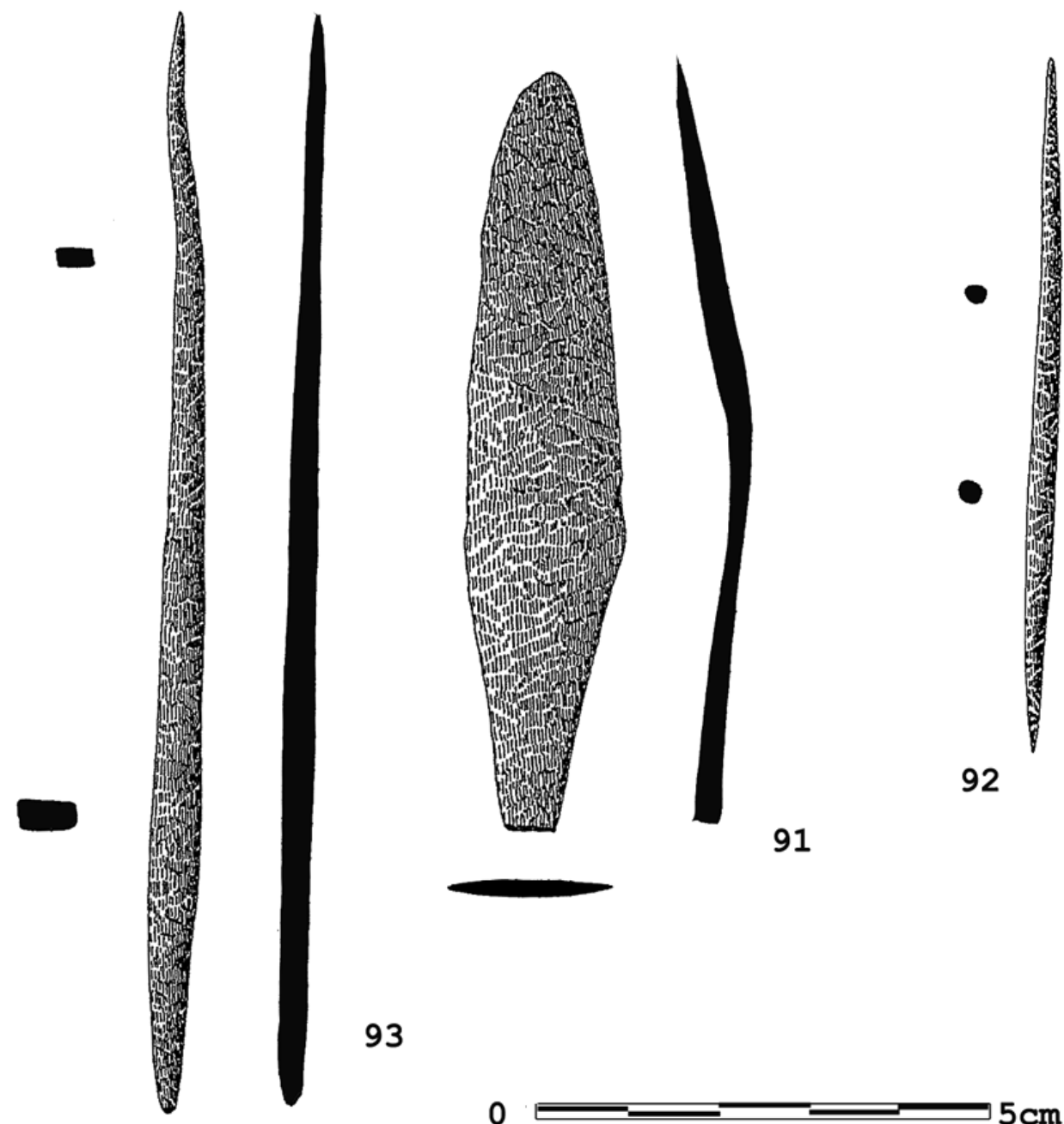

92

91

93

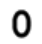

$5 \mathrm{~cm}$

Fig. 11. Dolmen de las Casas de Don Pedro. Ajuar metálico.

sólo a marcador territorial y la celebración de rituales como punto de reunión, pero lo que resulta obvio, a partir de los restos materiales, es que la ocupación de este sitio, como hábitat y/o marcador territorial de importancia local, no va más allá de finales del $\mathrm{V}$ y/o comienzos del IV milenio a.C., aunque no perdiera su carácter de hito.

Al Neolítico Final, comprendido entre finales del IV y/o comienzos del III milenio a.C., hemos adjudicado los asentamientos de Sierra Palacios II y, con ciertas dudas ante la escasez de restos, el Cerro del Castaño (Mapa 1).

Si como hemos señalado más arriba los menhires y las citadas estructuras formaban parte de un asentamiento más amplio que no sólo cumplía una función re- 
lacionada con la posesión y derecho a explotación del territorio, sino que se trata también de un hábitat, cabe plantear que a mediados del IV milenio a.C. la población se trasladara al cercano conjunto serrano, Sierra Palacios, comenzando la ocupación del asentamiento de Sierra Palacios II, en ladera, de donde proceden cerámicas de clara tipología y decoración neolíticas, continuando la ocupación este sitio durante el Neolítico Tardío o Final, hasta el primer tercio del III milenio a.C.

Las buenas tierras de labor, así como los abundantes pastos y los recursos cinegéticos, fueron los factores dominantes en el establecimiento de estas sociedades en la zona, que se afianzan en la parte central del valle, al tiempo que se extienden a la occidental, como pone de manifiesto el asentamiento del Cerro del Castaño, caso de no aportar en el futuro otros restos que indiquen una cronología claramente posterior.

Frente a la posible ocupación de una cavidad —Cueva de Agustín-y la zona llana donde se encuentran los menhires, los yacimientos se emplazan ahora, según los datos con que contamos, en laderas de cerros que se elevan sobre el Guadiato. La escasez de asentamientos tanto de esta fase como de la anterior, no permite plantear ni una agregación poblacional ni competencias entre grupos ya que la densidad poblacional del valle no parece ser elevada, pero el establecimiento de estos grupos en laderas revela un cambio en la elección de los lugares de hábitat, que pudo venir motivado, entre otros factores, por un control sobre la explotación del territorio productivo, muy en la línea de lo documentado en otros sectores regionales.

En este sentido, no en vano, cabe destacar que los menhires del yacimiento de las Casas de Don Pedro, pasan a formar parte de una cámara funeraria simple que alberga los restos óseos correspondientes a dos individuos, al menos. De este modo, se materializa aún más el derecho a explotación y control del territorio, ya que si bien los menhires debían resultar perfectamente visibles en el lugar elegido para su erección —una zona llana próxima a una vía de comunicación-, el gran túmulo que arropó la estructura funeraria potenció la visualización del espacio funerario, que continuará en uso (Mapa $1, n .^{\circ} 1$ ).

A esta fase atribuimos el enterramiento practicado en una pequeña diaclasa de Cueva de Agustín (Mapa 1, n. ${ }^{\circ}$ 7-B), donde se localizó (Vera, 1999) un escaso ajuar, de tipología semejante a la procedente de la $1 .{ }^{a}$ fase de enterramiento del Dolmen de las Casas de Don Pedro (Fig. 12), y restos correspondientes a unos 2 individuos.

De este modo, durante el Neolítico Tardío-Final, y como evidencian ambos enterramientos, se utilizan las cuevas como lugares de enterramiento, que conviven con los primeros sepulcros megalíticos. Aún teniendo en cuenta las circunstancias que rodean al hallazgo de Cueva de Agustín, donde pudo existir un ajuar algo más cuantioso del que nos ha llegado, los individuos enterrados en el Dolmen de las Casas de Don Pedro durante su primera fase de utilización gozaron de un estatus 

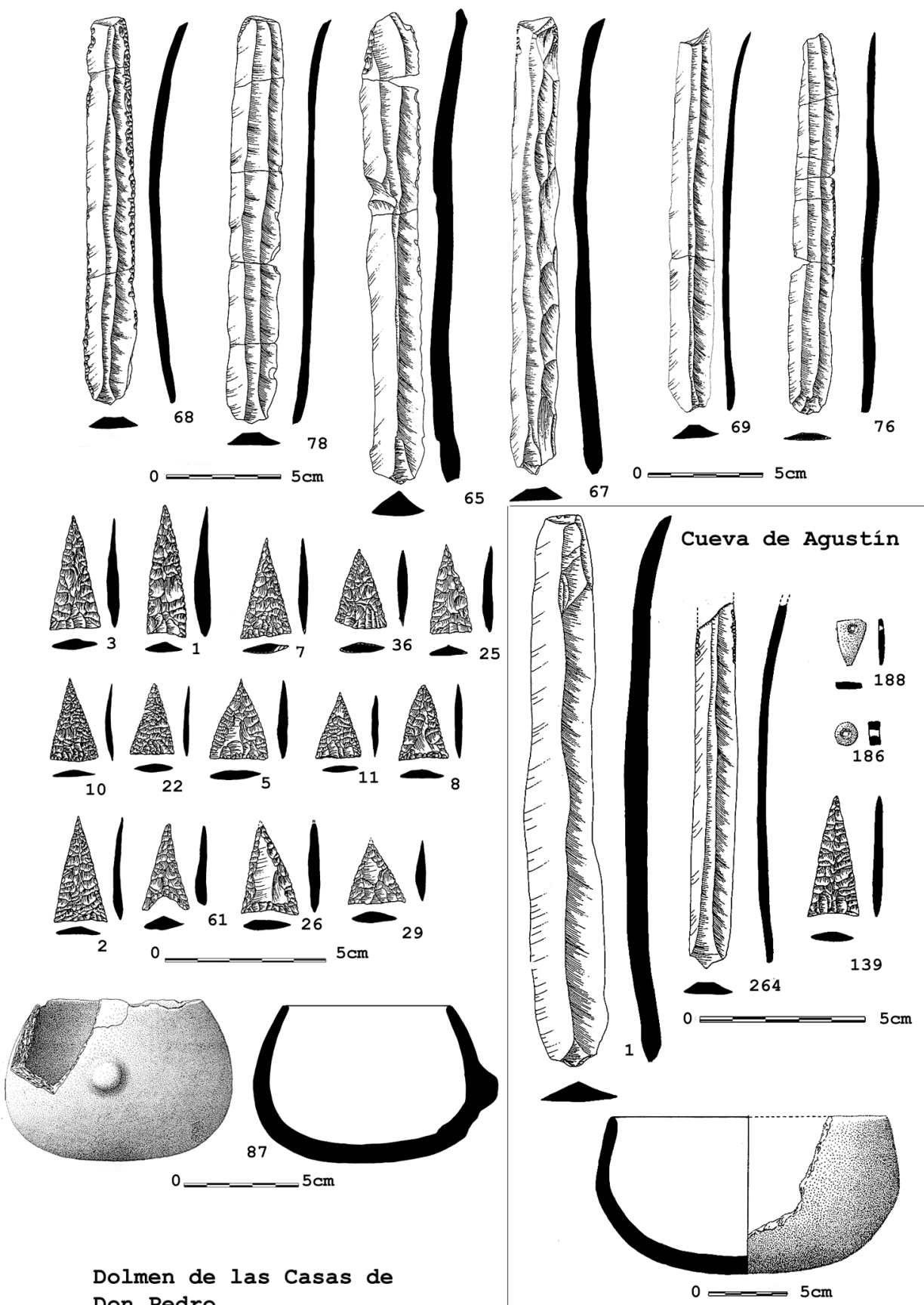

Dolmen de las Casas de Don Pedro

Fig. 12. Dolmen de las Casas de Don Pedro, ajuar. Cueva de Agustín. 
más elevado, puesto que, frente a una cavidad natural, el lugar donde se erigió esta estructura funeraria poseía previamente un carácter simbólico, y además de esto fue necesario invertir un considerable esfuerzo en la extracción y transporte de los ortostatos y el enorme túmulo que cubría la estructura. Todo esto permite atribuir especial importancia tanto al sepulcro como a los individuos en él enterrados.

Por el momento, no contamos con más sepulcros megalíticos cuya construcción se llevara a cabo durante el Neolítico Final, remitiendo los ajuares que se conocen, tanto de los excavados como de los expoliados en época reciente, al Calcolítico.

Según los restos materiales conservados, ni Sierra Palacios II ni el Cerro del Castaño presentan una continuidad habitacional más allá del Neolítico Tardío o Final. Con respecto al primero, resulta difícil defender de forma incuestionable que la población se trasladara a Sierra Palacios I durante la transición Neolítico/Calcolítico, escasamente documentado en la zona, ya que sólo se cuenta con Las Calerillas, resultando de todo punto insuficiente para cualquier tipo de planteamiento. Cabe señalar, no obstante, que se trata de un asentamiento bien situado, delimitado por dos cursos fluviales, y sobre tierras de considerable valor agrícola, de hecho están presentes los elementos de molturación. Quizá no estemos ante un asentamiento monofásico, como ya hemos apuntado, y la abundancia de cazuelas carenadas con respecto a los platos de borde engrosado indique la existencia de una fase ocupacional previa, Neolítico Final, continuando el hábitat durante la transición entre ambos períodos.

Por su parte, el Calcolítico Inicial se muestra algo más pródigo en hábitats: Los Delgados, El Calvario o La Granjuela I, Los Castillejos de la Granjuela, La Cinta y Huerta del Caño (Mapa 2). Aunque escasos, la ubicación de estos asentamientos evidencia una ocupación distinta a la de las etapas anteriores. Se abandona la zona central del valle (aceptando la inexistencia de esta primera fase calcolítica en Sierra Palacios I), ocupándose ahora dos puntos estratégicos del mismo, como son Los Castillejos de la Granjuela, en el extremo noroccidental y la Huerta del Caño, al este y sobre un estrechamiento del curso de Guadiato, junto a ellos destaca La Cinta - con una de las cotas más elevadas-, la ocupación más septentrional y dominando el acceso al Valle de Los Pedroches. Desde ellos se domina visualmente un amplio territorio, al tiempo que se encuentran sobre tierras muy aptas para el desarrollo de las prácticas económicas de producción. Además de estos asentamientos en altura, se ocupan también zonas sin posibilidades de defensa natural, como Los Delgados y El Calvario o La Granjuela I, éste sobre una suave elevación, pero situados en las proximidades de arroyos y sobre excelentes terrenos.

Tiene lugar, por lo tanto, una ocupación más efectiva del valle en la que prima el control visual del territorio y las tierras que permitían el desarrollo de las prácticas económicas, de hecho, los molinos están presentes en cuatro de los cinco asentamientos, atribuyendo su ausencia en Huerta del Caño a las características de la 
recogida. En lo que se refiere a la proximidad de los poblados en relación a los afloramientos de mineral de cobre, cabe decir que este factor no fue determinante en la elección de los lugares de hábitats, ya que las distancias más cortas implicadas superan los $4 \mathrm{kms}$ (Mapa 2).

Con respecto a la posibilidad de que durante el Calcolítico Inicial se produjese el traslado de población de Sierra Palacios II a Sierra Palacios I, debemos tener en cuenta la presencia, escasa si bien es verdad, de cazuelas carenadas, más abundantes en superficie que en estratigrafía. A esto hay que añadir que se excavó una zona muy reducida del yacimiento - sólo dos cuadrículas y de no muy amplias dimensiones-, hecho que permite considerar la probabilidad, a tenor de los restos superficiales, de una zona con una estratigrafía más amplia que revele un inicio de este hábitat a partir del Calcolítico Inicial. En este sentido, hay que tener en cuenta la importancia que debió poseer el lugar donde se ubicaban los menhires, que pasaron a formar parte de una cámara funeraria en el Neolítico Tardío-Final, el Dolmen de las Casas de Don Pedro, objeto de violación una vez depositados los primeros cadáveres, y de adición, tras aquella, de un pequeño corredor, que se prolongará durante el Calcolítico Pleno, como se desprende del ajuar metálico que acompañaba al enterramiento correspondiente a esta fase de ampliación, sellándose después el sepulcro, que no volverá a acoger más enterramientos, excepto ya en el II milenio a.C., en el túmulo. Estas remodelaciones, de menhires a dolmen de corredor, revelan, como hemos indicado, la trascendencia de este espacio, haciendo más sugerente aún la hipótesis de una ocupación de Sierra Palacios I a partir del Calcolítico Inicial.

Por último, cabe destacar que el poblado de Los Delgados no muestra evidencias de ocupación más allá del Calcolítico Inicial, mientras que La Cinta, Huerta del Caño y Los Castillejos de la Granjuela sí han ofrecido restos de la fase plena. La duración del hábitat de El Calvario o La Granjuela I debió ser mayor en el tiempo, aunque quizá discontinua si se tiene en cuenta su proximidad al poblado de Los Castillejos de La Granjuela, de mayor entidad, como plantea Vera (1999).

En cuanto a los enterramientos, aunque no podemos precisar los ajuares que corresponden a inhumaciones practicadas durante el comienzo del Calcolítico, dadas las características de estos registros - en su casi totalidad obtenidos de forma clandestina-, resulta lícito pensar que la construcción de bastantes sepulcros megalíticos se llevara a cabo durante esta fase, como parecen indicar los frecuentes foliáceos de base recta, que señalan cierta antigüedad (Gavilán y Vera, 1994).

A comienzos del Calcolítico Pleno se observa una ocupación más densa de todo el Alto Valle del Guadiato, jalonando los poblados el curso fluvial, desde su nacimiento, en la Calaveruela, hasta el paso estrecho que se forma a corta distancia de la Huerta del Caño; así como los puntos estratégicos que se elevan sobre los afluentes de ambas márgenes del río (Mapa 3). 
Atendiendo a la cantidad de restos aportados por los yacimientos, único criterio al que podemos acudir teniendo en cuenta que estamos tratando en la casi totalidad de los casos de materiales de superficie, los poblados de mayor entidad son La Calaveruela, La Cinta, Los Castillejos de La Granjuela, Los Castillejos de Fuente-Obejuna, Cerro de las Piedras, El Peñón, Sierra Palacios I, La Cornuda, Cerro del Ermitaño y Huerta del Caño (Mapa 3). En el caso de Los Castillejos de La Granjuela se ha observado la existencia de estructuras de fortificación que defienden al poblado por sus lados sur y este (Vera, 1999).

Por su parte, El Calvario o La Granjuela I pasaría a ser un asentamiento dependiente de Los Castillejos de La Granjuela, como bien apunta Vera (1999); mientras que la ocupación de Cerro Masatrigo podría relacionarse con Los Castillejos de Fuente-Obejuna o con El Peñón, al estar prácticamente equidistante de ambos, Castillo de Belmez con Sierra Palacios I, y La Lozana y Cerro del Molino podrían responder a ocupaciones dependientes de La Cornuda (Mapa 3).

La situación de los poblados, tanto los de mayor entidad como de los secundarios, muestra un control sobre el territorio más productivo del valle y las vías naturales de comunicación, destacando ahora la proximidad de varios poblados a los afloramientos de cobre, caso de Los Castillejos de Fuente-Obejuna, Cerro de las Piedras, Sierra Palacios I, La Cornuda y Cerro del Ermitaño (Mapa 3), habiendo proporcionado los tres primeros artefactos de metal o bien elementos relacionados con la extracción del mineral. Destaca, por otra parte, la presencia de útiles de cobre en El Peñón y de escorias en Los Castillejos de la Granjuela, situados ambos a unos $5 \mathrm{kms}$ de los afloramientos de mineral más próximos. Finalmente, resulta interesante subrayar el hecho de que se ha producido un abandono de los hábitats situados en zonas llanas y de fácil acceso, excepción hecha de La Granjuela I o El Calvario, eligiéndose para los poblados cerros aislados o cerros que forman parte de conjuntos más amplios pero con excelentes posibilidades de defensa naturales.

Si atendemos a los restos materiales procedentes de los sepulcros megalíticos excavados y expoliados, la mayoría de ellos estuvieron vigentes a esta fase del Calcolítico, sin embargo no hay que descartar que la construcción de algunos de ellos comenzara ya el Neolítico Tardío-Final, como ocurre con el ya referido Dolmen de las Casas de Don Pedro, y, sobre todo, en el Calcolítico Inicial, como indicábamos más arriba. Cabe suponer que la consolidación de las prácticas económicas y el control de territorio productivo tanto para agricultura como para la ganadería y el control sobre las vías de comunicación motivaron la erección de nuevos sepulcros megalíticos, continuando en uso la mayoría de los existentes, formando así auténticas necrópolis dolménicas, como las de La Calaveruela, la del Cerro de las Piedras y la de Sierra Palacios I (Mapa 3).

Estas necrópolis se encuentran lejos de presentar una uniformidad arquitectónica de los sepulcros. Así, en la de La Calaveruela, la más expoliada, están presentes los tholoi, con o sin camarilla lateral, las cámaras a base de lajas de pizarra, 
los dólmenes de corredor, ortostáticos y de bloques de mediano tamaño, y las galerías, mientras que en la necrópolis del Cerro de las Piedras están presentes, según los restos conservados, las dos últimas arquitecturas, y los dólmenes de corredor, por el momento, en la de Sierra Palacios (Gavilán y Vera, 1994), habiéndose documentado recientemente en ésta la cubrición del túmulo de tierra con una capa de piedras (Gavilán, e.p.).

La extensión que abarca la necrópolis de Sierra Palacios, aproximadamente 6 $\mathrm{km}$ desde el poblado hasta el megalito más alejado (unos 8 si se incluyen los de Doña Rama I y II), y las diferencias cronológicas que se aprecian entre los restos materiales aportados por el Dolmen de las Casas de Don Pedro en su primera fase de utilización, Neolítico Final, con respecto a los documentados en el Dolmen de la Fuente del Corcho, pese a la escasez de restos recuperados por el expolio tanto tras la deposición de los cadáveres como en época actual (Gavilán, e.p.), indican la importancia que adquiere este poblado y el deseo de ejercer un control sobre los recursos económicos y las vías de comunicación de un amplio territorio a través de los sepulcros megalíticos. Este planteamiento evidentemente es aplicable a las otras dos necrópolis, la del Cerro de las Piedras y la de La Calaveruela, contando ésta con diferentes tipos de arquitecturas megalíticas que han aportado restos materiales de amplia cronología calcolítica.

Tomando como criterio la presencia de cerámicas campaniformes, los poblados de La Calaveruela, Sierra Palacios I, La Cinta, Los Castillejos de La Granjuela, Los Castillejos de Fuente-Obejuna, Cerro de las Piedras, El Peñón, La Cornuda y Cerro del Ermitaño continúan su trayectoria durante el Calcolítico Final (Mapa 3). La ausencia de estos recipientes en Huerta del Caño no refleja de forma segura su abandono, pero quizá esté indicando que los poblados que cuentan con ellos crecen en importancia al tratarse de unas vasijas de alto contenido social y simbólico, ejerciendo un mayor control sobre las vías naturales que conectan con otros sectores peninsulares.

Atendiendo a las características del poblamiento durante el Calcolítico en el Alto Valle del Guadiato, que hemos expuesto, resulta evidente que este sector se vincula con nitidez a lo largo de todo el período con Extremadura. De hecho, parte de la necrópolis dolménica de La Calaveruela se encuentra ya en tierra extremeña, y en algunos de los sepulcros del sector que analizamos se documentan una vasija de caliza -Delgados I- e ídolos-placa, completos o no -Delgados I y Sierrezuela I y Huerta del Caño-, que también vinculan a nivel de elementos materiales esta zona con las tierras meridionales extremeñas, donde estos elementos son muy frecuentes. Asimismo, la situación de los poblados calcolíticos del Alto Valle del Guadiato está poniendo de manifiesto que este sector no sólo ofrece semejanzas a diferentes niveles, sino que pudo formar parte del territorio planteado por Hurtado (2003) para la lindante comarca de Azuaga-Llerena, tratándose de una prolongación del mismo, aunque no contamos con asentamientos fortificados - salvo, por el momento, los Castillejos de la Granjuela, caso de confirmarse-. Visto así, los 
asentamientos del Alto Valle del Guadiato pudieron actuar de nexo entre las relaciones que plantea el citado autor "tanto en dirección al Valle del Guadalquivir como a Tierra de Barros» (Hurtado, 2003:261), enlazando aquellos a través de los de El Vacar y Cerro Muriano, en la sierra, con los situados en el centro del Valle del Guadalquivir.

En cuanto a las prácticas funerarias, como es usual en otros sectores peninsulares, continúa la deposición del cadáver en determinados sepulcros megalíticos, como evidencian los fragmentos de cerámica campaniforme en el Dolmen de Sierrezuela I y en los túmulos de Mina de San Antonio o La Jabalina y Fuente del Corcho, constatándose también la inhumación individual en grieta o covacha, como La Retuerta.

A nivel general, y a lo largo de todo el Calcolítico, se observa un establecimiento por parte de estas sociedades en lugares estratégicos y fácilmente defendibles de forma natural, desde los que se dominan vastos territorios, ubicándose en terrenos idóneos para la economía agropecuaria. Estos fueron los factores más importantes en la elección de los lugares de hábitats, y no tanto la proximidad a los filones de mineral, como se desprende de la estratigrafía de Sierra Palacios I, en la que las actividades metalúrgicas se constatan ya bien avanzada la ocupación del emplazamiento. Los poblados de El Peñón y Los Castillejos de Fuente-Obejuna son los que han aportado mayor cantidad de artefactos metálicos, estando el segundo a corta distancia de un afloramiento, mientras que el primero se sitúa a unos 4-5 kms. de los afloramientos más próximos.

La expresión de control del valle que manifiestan los poblados se complementa perfectamente con la situación de los sepulcros megalíticos (Mapas 3 y 4). Estos se encuentran principalmente en la margen derecha del Guadiato y sus afluentes, excepción hecha de la necrópolis de La Calaveruela, situada casi en su totalidad en la margen izquierda de la cabecera del río, mientras que los poblados se encuentran en mayor medida en la margen izquierda, pero tanto unos como otros se sitúan en pasos naturales de comunicación, que siglos más tarde constituirán diferente tipos de vías pecuarias que recorren la zona, de las que sólo vamos a atender a Cañadas, Cordeles y Veredas (Mapa 4). Así, la Cañada Real Segoviana finaliza en el abrevadero situado al pie de casco urbano de FuenteObejuna, donde confluye con un Cordel procedente de Extremadura que se bifurca en dos, uno se dirige hacia el sur hasta Hornachuelos, pasando junto al poblado de La Vaquera y el conjunto de dólmenes que conforman su necrópolis, no tenidos en cuenta en este trabajo; el otro discurre por el Valle del Guadiato hasta enlazar con la Cañada Real Riojana, al este y próxima a Espiel; el primer tramo de este Cordel se desarrolla por la margen derecha del río, pasando a la izquierda a la altura de Sierra Palacios. De este Cordel y a escasos km. de Fuente-Obejuna salen dos Veredas, una describe un arco en dirección oeste para enlazar con el Cordel que comunica dicha localidad con Hornachuelos, y la otra pasa al pie de la vertiente meridional de la Sierra de los Santos en dirección a Vi- 
llanueva del Rey, para finalizar en el Cordel que se une a la Cañada Real Riojana, cercana a Espiel y que pasa por el núcleo dolménico del Valle de Los Pedroches.

Aunque con esta breve exposición de las vías pecuarias que pasan por la zona objeto de estudio pudiera parecer que estamos defendiendo un comienzo de la trashumancia a partir del Calcolítico — planteamiento defendido por Higgs (1976) y rechazado rápidamente por otros investigadores (Cara y Rodríguez, 1987)-, no es esta, en absoluto, nuestra intención, puesto que aún admitiendo un aumento poblacional relativamente importante durante dicho período, y por tanto una competencia por los terrenos productivos, la capacidad de sustentación del Alto Valle del Guadiato, con amplias tierras de valor agrícola y sobre todo zonas de pasto, debía ser suficiente para el desarrollo de una economía agropecuaria en la que no se requería la práctica trashumante o la transterminante. Pero sí subrayar que los sepulcros megalíticos ejercieron en la gran mayoría de los casos como marcadores territoriales y, como tales, se emplazan lógicamente en las cercanías o sobre los pasos naturales de comunicación (Mapa 4). De este modo, formen o no parte de una necrópolis, los sepulcros se emplazan siempre entre dos pasos naturales de comunicación o a corta distancia de ellos y de los vados, caso de formar parte una necrópolis, o muy próximos a aquellos en caso de tratarse de megalitos aislados, como ocurre con el del Pantano de Sierra Boyera, Los Pánchez, los de Doña Rama y el del Pantano de Puente Nuevo.

Sin menoscabo de lo anterior, hay que indicar que se observa una clara discrepancia entre la situación de los poblados y las arquitecturas megalíticas. Así, mientras los primeros se alinean en todo el valle del curso superior del río, en ambas márgenes aunque principalmente en la izquierda, las estructuras megalíticas funerarias se localizan principalmente en la derecha, sobre todo a partir de la confluencia de los arroyos Calerillas y Montuenga con el Guadiato. Esta circunstancia no puede atribuirse íntegramente al hecho de que se evitara conscientemente la erección de estos espacios funerarios en las tierras constituidas por sedimentos aluviales, de gran valor, que se reservarían para la agricultura, puesto que la necrópolis de La Calaveruela se levantó en su mayor parte en la margen izquierda del río, sucediendo lo mismo en un sepulcro de la de Sierra Palacios y en el dolmen de La Jabalina, situados sobre excelentes tierras.

En definitiva, a través de los poblados se ejerce un control del territorio existente al norte del curso del Guadiato, mientras que las necrópolis y sepulcros aislados actúan como marcadores territoriales al sur del río, ejerciendo un control sobre los pasos naturales de comunicación que, a partir de la margen derecha del Guadiato, conducen al interior de Sierra Morena, encontrándose en las proximidades del más destacado de ellos, que comunica las actuales localidades de Fuente-Obejuna con Hornachuelos, el poblado calcolítico de La Vaquera, que cuenta con necrópolis dolménica, estando próximo también el sepulcro megalítico de La Serrezuela, en Posadas, ya en el Valle del Guadalquivir. 
Quizá este reparto de funciones, poblados controlando el territorio al norte del río Guadiato y sepulcros al sur, explique la ausencia de megalitos correspondientes a poblados de la entidad de El Peñón, los Castillejos de Fuente Obejuna, los Castillejos de La Granjuela o La Cinta, pero en este caso cabe preguntarse dónde se enterraron sus habitantes, cuestión que, por el momento, queda sin explicación.

\section{BIBLIOGRAFÍA}

AcostA, P. (1986): «El Neolítico en Andalucía Occidental: Estado actual», en Homenaje a L. Siret (Cuevas de Alamanzora, 1985), pp. 136-151.

AsqueRINO, M.D. (1985): «Ídolos Eneolíticos procedentes del Norte de Córdoba», Ifigea, II, pp. 177-180. BENITO ONTAÑón, A. de (1976): «Nuevos hallazgos de la cultura del vaso campaniforme en la provincia de Córdoba», C.P.U.Gr., 1, pp. 111-117.

Bernier, J., SÁNCHEZ, C., JimÉnEZ, J. y SÁnCHEZ, A. (1981): Nuevos yacimientos arqueológicos en Córdoba y Jaén, Córdoba, 110 p.

BLÁZquez MARTíneZ, J. M. (1981): «Poblado de esclavos mineros en Fuenteovejuna», Revista de Arqueología, 3, pp. 7-12.

Bueno, P., Balbín, R. de, Barroso, R., Alcolea, J. J., Villa, A. y Moraleda, A. (1999): El Dolmen de Navalcán. El poblamiento megalítico en el Guadyerbas, Instituto Provincial de Investigaciones y Estudios Toledanos, Toledo.

Cabrero García, R. (1985): «Tipología de los sepulcros calcolíticos en Andalucía Occidental», Huelva Arqueológica, VII, pp. 207-263.

- (1988 a): El Fenómeno Megalítico en Andalucía Occidental, Universidad de Sevilla (microfichas).

- (1988 b): El yacimiento Calcolítico de Los Delgados. Fuente Obejuna (Córdoba), Córdoba.

CÁmARA, J. A., Molina, F., Afonso, J. A. (2005): «La cronología absoluta de Los Castillejos en las Peñas de los Gitanos (Montefrío, Granada)», en Arias, P., Ontañón, R. y García-Moncó, C. (eds.): III Congreso del Neolítico en la Península lbérica (Santander, 5 a 8 de octubre de 2003), Universidad de Cantabria (Monografías del Instituto Internacional de Investigaciones Prehistóricas de Cantabria, 1), Santander, pp. 841-855.

CARA, L. y RodRíGueZ, J. M. (1987): «Trashumancia ganadera y megalitismo. El caso del valle medio-bajo del río Andaráx (Almería)», XVIII Congreso Nacional de Arqueología, pp. 235-248.

CARBonell y Trillo-FigueroA, A. (1923): «Contribución al estudio de la Prehistoria cordobesa. La zona de Fuente Obejuna-Valsequillo», B.R.A.Co., 3, pp. 75-83.

- (1925): «Valores prehistóricos de la Cuenca Alta del Guadiato», B.R.A.Co., 13, pp. 291-300.

- (1945): "Noticias varias recopiladas en los antecedentes de campo. Monumentos megalíticos, restos de estaciones prehistóricas, paleolíticas, neolíticas, castros, castillos, inscripciones y otros restos", B.R.A.Co., 54, pp. 317-326.

- (1949): «Antigüedades cordobesas. Restos varios de diferentes órdenes recogidos en itinerarios de campo, en la provincia de Córdoba», B.R.A.Co., 61, pp. 85-90.

C.E.B.A.C. (1971): Estudio agrobiológico de la provincia de Córdoba, Madrid.

Cepillo Galvín, J. J. (1994): El Calcolítico en el Alto Valle del Guadiato. El poblado de La Calaveruela y su necrópolis dolménica (Fuente Obejuna, Córdoba), Universidad de Cádiz (Memoria de Licenciatura inédita).

Escacena, J. L., Rodríguez de Zuloaga, M. y LadRón de Guevara, I. (1996): Guadalquivir salobre. Elaboración prehistórica de sal marina en las antiguas bocas del Río, Sevilla.

Gavilán Ceballos, B. (1985): «Materiales prehistóricos de la Cueva del Cañaveralejo (Adamuz, Córdoba)», Ifigea, II, pp. 53-77.

— (1986 a): «Resultados preliminares de un corte estratigráfico en Sierra Palacios (Belmez, Córdoba)», B.R.A.Co., 111, pp. $81-88$.

— (1986 b): «Excavaciones en Sierra Palacios (Belmez, Córdoba)», Revista de Arqueología, 61, pp. 29-32.

— (1986 c): «Materiales prehistóricos de la Cueva del Cañaveralejo (Adamuz, Córdoba)», Ifigea, II, pp. 53-77.

— (1987 a): «Ídolos procedentes del yacimiento de Sierra Palacios (Belmez, Córdoba)» Estudios de Prehistoria Cordobesa, 3, pp. 81-88. 
— (1987 b): «Excavación Arqueológica de Urgencia en el yacimiento de Sierra Palacios (Belmez, Córdoba), 1985", A.A.A. (III, Actividades de Urgencia), pp. 102-104.

- (1987 b): «Excavación Arqueológica de Urgencia en el Dolmen de las Casas de Don Pedro (Belmez, Córdoba)», A.A.A. (III, Actividades de Urgencia), pp. 118-120.

- (e.p.): «Excavación Arqueológica Puntual en el Dolmen de la Fuente del Corcho (Belmez, Córdoba)», A.A.A.

GaVILÁN, B. y VerA, J. C. (1989-90): «La Edad del Cobre en el Alto Valle del Guadiato (tramo Fuente Obejuna-Belmez, Córdoba): Características de los asentamientos y evolución diacrónica», C.P.U.Gr., 1415, pp. 137-155.

- (1994): «Aproximación al fenómeno megalítico en el Alto Valle del Guadiato», I/ Congreso de Historia de Andalucía (Córdoba, 1991). I, Córdoba, pp. 133-146.

- (2001): «Excavación Arqueológica (I.A.U. de apoyo a la restauración) en el Dolmen de las Casas de Don Pedro (Belmez, Córdoba)", A.A.A. (III, Actividades de Urgencia), pp. 291-296.

- (2005): «Neolítico y megalitismo prefunerario en Andalucía», en Arias, P., Ontañón, R. y García-Moncó, C. (eds.): III Congreso del Neolítico en la Península Ibérica (Santander, 5 a 8 de octubre de 2003), Universidad de Cantabria (Monografías del Instituto Internacional de Investigaciones Prehistóricas de Cantabria, 1), Santander, pp. 535-541.

Gavilán, B., Moreno, A., Ventura, A. y Vera, J. C. (1991): «Localización de sepulturas megalíticas situadas en el sector septentrional de la provincia de Córdoba. I. Octubre a Diciembre de 1987 », A.A.A. (III, Actividades de Urgencia), pp. 107-113.

HIGGS, E. S. (1976): «The history of European agricultura: the uplands», Philosophical Transactions of the Royal Society of London, Series B, 275, pp. 159-173.

HURTADO, V. (2003): «Fosos y fortificaciones entre el Guadiana y el Guadalquivir en el III milenio a.C.: Evidencias del Registro Arqueológico", en Oliveira Jorge, S. (coord.): Recintos Murados da Pré-Historia Recente, Mesa Redonda Internacional, Porto-Coimbra, pp. 241-268.

LeISNER, G. y V. (1943): Die Megalithgräber der Iberischen Halbinsel. Der Süden. Romisch-Germanische Forchungen, Band 17, Berlin.

martín de la Cruz, J. C., Vera, J. C., Gavilán, B. y Perlines, M. (2005): «Un colgante de cornalina de manufactura oriental procedente de la provincia de Córdoba", El Período Orientalizante. Actas del Simposio Internacional de Arqueología de Mérida: Protohistoria del Mediterráneo Occidental. Vol. 11 (Mérida, 2005), Anejos de Archivo Español de Arqueología, XXXV, pp. 503-510.

Murillo Redondo, J. F. (1986 a): Eneolítico y Edad del Bronce en el Norte de la provincia de Córdoba, Universidad de Córdoba (Memoria de Licenciatura inédita).

- (1986 b): «Nuevos yacimientos calcolíticos en el sector noroccidental de la provincia de Córdoba», Estudios de Prehistoria Cordobesa, 1, pp. 77-94.

Pérez, C., Afonso, J. A., Cámara, J. A., Contreras, F. y Lizacano, R. (1999): «Clasificación cultural, periodización y problemas de compartimentación en el Neolítico de la Alta Andalucía», en Bernabeu, J. y Orozco, T. (eds.): Il Congrés del Neolitic a la Península Ibérica (Valencia, 1999), Saguntum, Extra2, pp. 485-492.

Vaquerizo, D., Murillo, J. F., Carrillo, J. R., Moreno, M. F., León, A., Luna, M. ${ }^{a}$ D. y Zamorano, A. M. (1994): El Valle Alto del Guadiato (Fuenteobejuna, Córdoba), Universidad de Córdoba, Servicio de Publicaciones, Córdoba.

VERA RODRíGUEZ, J. C. (1995): Los hábitats y las necrópolis prehistóricas del entorno de Sierra Palacios (Belmez, Córdoba). La industria lítica tallada en la secuencia cultural del Iller milenio a.C., Universidad de Córdoba (Publicación en microficha n. ${ }^{\circ} 123$ ).

- (1999): El Calcolítico en el Alto Valle del Guadiato: los hábitats y las necrópolis prehistóricas del entorno de Sierra Palacios, Universidad de Córdoba (Publicación en microficha n. ${ }^{\circ}$ 189). 